NIST NCSTAR 1-1H

Federal Building and Fire Safety Investigation of the World Trade Center Disaster

\title{
Post-Construction Modifications to Fire Protection and Life Safety Systems of the World Trade Center Towers
}

Raymond A. Grill

Duane A. Johnson 


\section{ABSTRACT}

This report was prepared to support the analysis of building and fire codes and standards of the National Institute of Standards and Technology World Trade Center (WTC) Investigation. The purpose of this report is to document the Port Authority of New York and New Jersey guidelines for inspection, repair, and modifications to fire protection and egress systems in WTC 1,2, and 7. This includes guidelines governing the inspection and upgrading of fire alarm and fire suppression systems; the reapplication of fireproofing; and the upgrading of elevators, hoistways, and elevator lobbies.

This report also documents repairs and modifications made to the fire protection and life safety systems on the affected floors of WTC 1 and WTC 2.

Keywords: Compartmentation, elevators, emergency power, fire alarm, fire protection, fire safety, fire sprinklers, high-rise buildings, inspections, interior finish, means of egress, pressurization, venting, voice communication, World Trade Center. 
This page intentionally left blank. 


\section{TABLE OF CONTENTS}

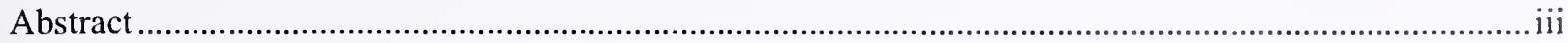

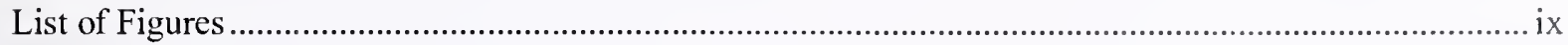

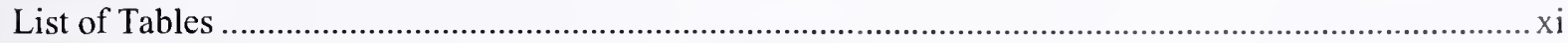

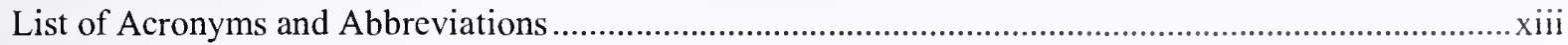

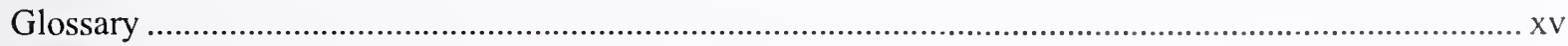

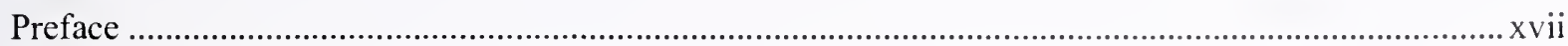

\section{Section I}

PANYNJ Guidelines for Inspection, Repair, and Modifications to Fire Protection

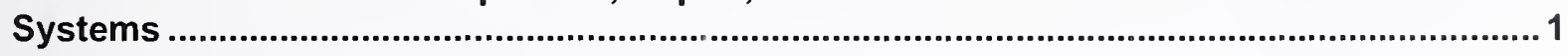

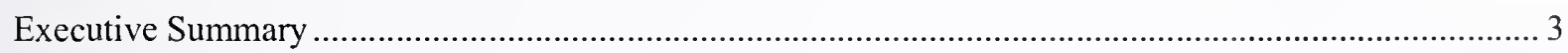

Chapter 1

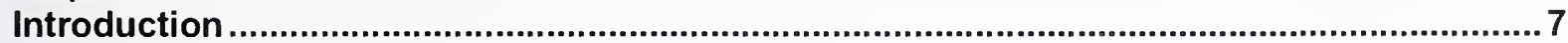

Chapter 2

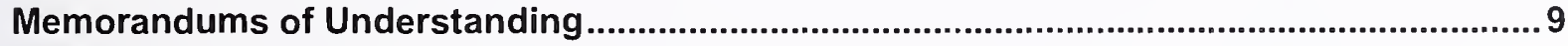

\section{Chapter 3}

Tenant Construction Review Manuals .........................................................................11

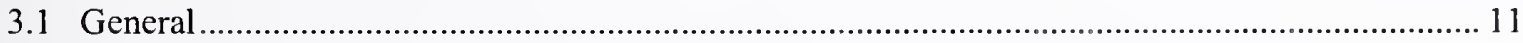

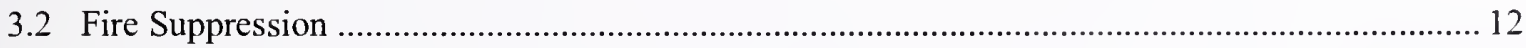

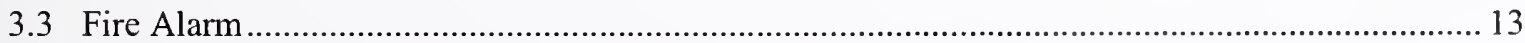

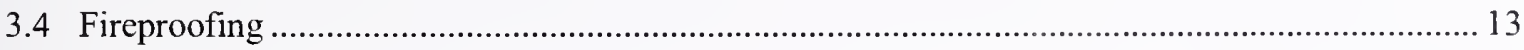

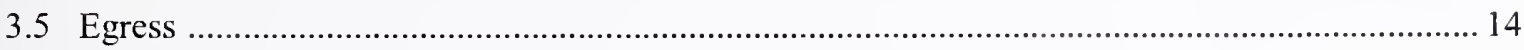

\section{Chapter 4}

Design Guidelines............................................................................................. 15

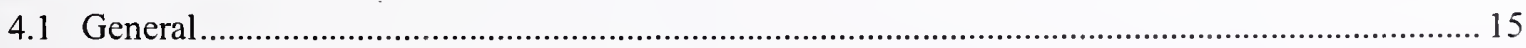

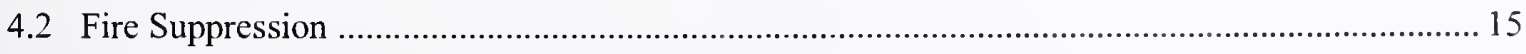

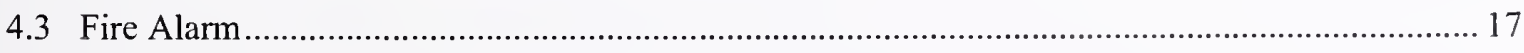

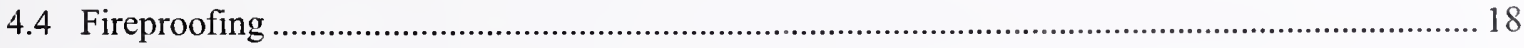

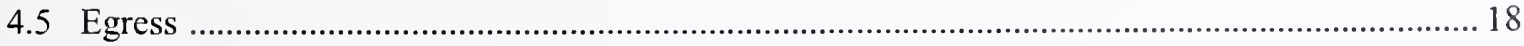

4.6 Elevators and Hoistways ................................................................................................. 19 


\section{Chapter 5}

Operation and Maintenance Manuals

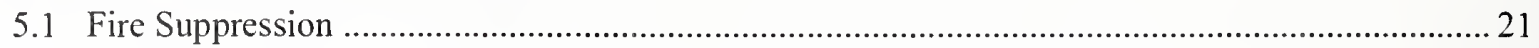

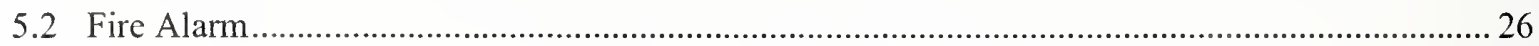

Chapter 6

Port Authority Facility Condition Survey Program .................................................... 35

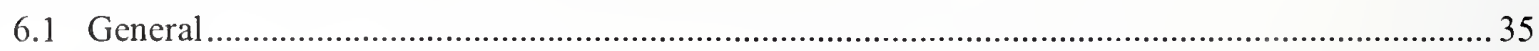

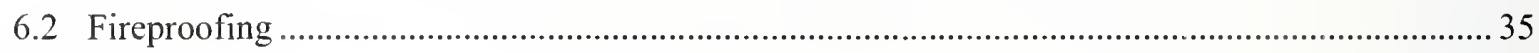

Chapter 7

Structural Integrity Testing and Inspection Program .............................................. 37

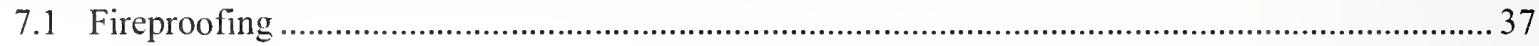

\section{Chapter 8}

Tenants Manual.................................................................................................. 39

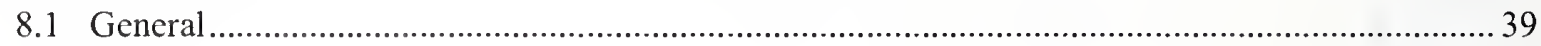

Chapter 9

Other Documents .................................................................................... 41

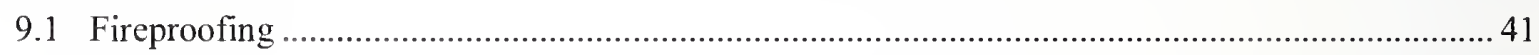

\section{Chapter 10}

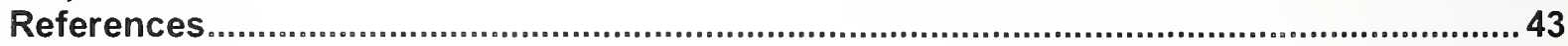

\section{Section II}

Post-Construction Fire Protection and Life Safety Modifications to the World Trade Center Towers .......................................................................................................45

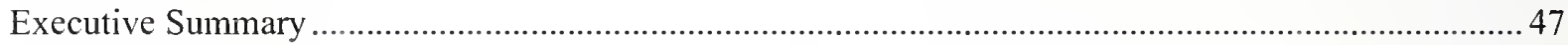

\section{Chapter 11}

Introduction

Chapter 12

Base Building Modifications to Affected Floors ..................................................................51

12.1 Modification Programs in Progress or Completed as of September 11, 2001 ..........................5 51

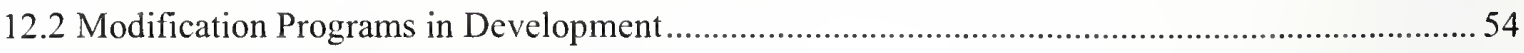




\section{Chapter 13}

Tenant Modifications to Affected Floors 55

13.1 WTC 1 Tenant Alterations on Affected Floors (78-84) 56

13.2 WTC 2 Tenant Alterations on Affected Floors (94-98)

\section{Chapter 14}

References.

Appendix A

Reproduction of Report on Fire Safety of the World Trade Center. 
This page intentionally left blank. 


\section{LIST OF FIGURES}

Figure P-1. The eight projects in the federal building and fire safety investigation of the WTC disaster.

xix 
This page intentionally left blank. 


\section{LIST OF TABLES}

Table P-1. Federal building and fire safety investigation of the WTC disaster. ..................................

Table P-2. Public meetings and briefings of the WTC Investigation...................................................

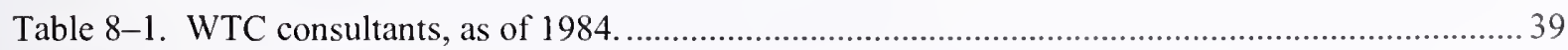

Table 12-1. Contracts involved with the fire alarm upgrades. ..................................................... 52

Table 13-1. Summary of WTC 1 tenant modifications within affected floors.................................... 56

Table 13-2. Summary of WTC 2 tenant modifications within affected floors ...................................5 57 
This page intentionally left blank. 


\section{LIST OF ACRONYMS AND ABBREVIATIONS}

\section{Acronyms}

$\begin{array}{ll}\text { ADA } & \text { Americans with Disabilities Act } \\ \text { ASTM } & \text { American Society for Testing and Materials } \\ \text { BCNYC } & \text { Building Code of the City of New York (Local Law 76) } \\ \text { BFP } & \text { Bureau of Fire Prevention } \\ \text { FDNY } & \text { New York City Fire Department } \\ \text { HVAC } & \text { heating, ventilating, and air conditioning } \\ \text { LERA } & \text { Leslie E. Robertson Associates } \\ \text { MER } & \text { Mechanical Equipment Room } \\ \text { MOU } & \text { Memorandum of Understanding } \\ \text { MPC } & \text { Maintenance Procedure Card } \\ \text { NFPA } & \text { National Fire Protection Association } \\ \text { NYCDB } & \text { New York City Department of Buildings } \\ \text { NIST } & \text { National Institute of Standards and Technology } \\ \text { PANYNJ } & \text { Port Authority of New York and New Jersey } \\ \text { R\&D } & \text { research and development } \\ \text { WTC } & \text { World Trade Center } \\ \text { WTC 1 } & \text { World Trade Center 1 (North Tower) } \\ \text { WTC 2 } & \text { World Trade Center 2 (South Tower) } \\ \text { WTC 7 } & \text { World Trade Center 7 }\end{array}$

\section{Abbreviations}

$\begin{array}{ll}{ }^{\circ} \mathrm{F} & \text { degrees Fahrenheit } \\ \mathrm{cfm} & \text { cubic foot per minute } \\ \mathrm{ft} & \text { foot } \\ \mathrm{ft}^{2} & \text { square foot } \\ \mathrm{in} . & \text { inch } \\ \mathrm{lb} & \text { pound } \\ \mathrm{V} & \text { volt }\end{array}$


W

$\mathrm{yd}^{2}$

watt

square yard 


\section{GLOSSARY}

active fire protection - A means to help prevent the loss of life and property from fire by cxtinguishing, suppressing or controlling a fire through functional systems. Sprinkler systems, fire alarm systems, and smoke control systems are examples of active fire protection.

area of refuge - A floor arca to which egrcss is madc through a horizontal cxit or supplemental vertical exit.

combustible - A material that is not determined to be noncombustible.

damper - A device installed in heating, ventilating, and air conditioning ductwork used to prevent the spread of fire and/or smoke. Dampers are provided to maintain a fire resistance rating of the assembly being penetrated.

detector - An initiation device that automatically detects a change in state, such as presence of smoke, high temperature or abnormal rate of temperature rise.

fire alarm system - A system, automatic or manual, arranged to give a signal indicating a fire emergency and initiate the appropriate response.

fire resistance rating - The time in hours that materials or their assemblies will withstand fire exposure as determined by a fire test.

fireproofing - Materials or assemblies used to provide a fire resistance rating to a building component.

firestop - A solid or compact, tight closure to retard the spread of flames or hot gases within concealed spaces.

initiation device - A system component that originates a change in state signal in the fire alarm system. An initiation device begins the life safety processes, such as evacuation, heating, ventilating, and air conditioning shut down, elevator recall; etc.

manual fire alarm box - A manually operated initiation device that originates a change-in-state signal in the fire alarm system.

means of egress - A continuous and unobstructed path of vertical and horizontal travel from any point in a building to a public way. The means of egress consists of the exit access, the exit, and the exit discharge.

noncombustible - A material that, in the form in which it is used in construction, will not ignite and burn when subjected to fire. However, any material which liberates flammable gas when heated to any temperature up to $1,380^{\circ} \mathrm{F}$ for $5 \mathrm{~min}$ shall not be considered noncombustible. 
notification appliance - A fire alarm system component such as a bell, horn, speaker, or strobe that provides audible, tactile, or visible outputs, or any combination thereof.

passive fire protection - Fire protection features that are incorporated into the building construction or building materials that do not rely on active fire protection methods to limit fire ignition, fire growth or material failure. Fire separations and divisions, sprayed-on fire proofing and enclosing structural members with noncombustible materials are examples of passive fire protection.

smoke and heat venting - A process used to move products of combustion to the outdoor air. 


\section{PREFACE}

\section{Genesis of This Investigation}

Immediately following the terrorist attack on the World Trade Center (WTC) on September 11, 2001, the Federal Emergency Management Agency (FEMA) and the American Socicty of Civil Engineers began planning a building performance study of the disaster. The week of October 7, as soon as the rescue and search efforts ceased, the Building Performance Study Team went to the site and began its assessment. This was to be a brief effort, as the study team consisted of experts who largely voluntcered their time away from their other professional commitments. The Building Performance Study Team issued its report in May 2002, fulfilling its goal "to determine probable failure mechanisms and to identify areas of future investigation that could lead to practical measures for improving the damage resistance of buildings against such unforeseen events."

On August 21, 2002, with funding from the U.S. Congress through FEMA, the National Institute of Standards and Technology (NIST) announced its building and fire safety investigation of the WTC disaster. On October 1, 2002, the National Construction Safety Team Act (Public Law 107-231), was signed into law. The NIST WTC Investigation was conducted under the authority of the National Construction Safety Team Act.

The goals of the investigation of the WTC disaster were:

- To investigate the building construction, the materials used, and the technical conditions that contributed to the outcome of the WTC disaster.

- To serve as the basis for:

- Improvements in the way buildings are designed, constructed, maintained, and used;

- Improved tools and guidance for industry and safety officials;

- Recommended revisions to current codes, standards, and practices; and

- Improved public safety.

The specific objectives were:

1. Determine why and how WTC 1 and WTC 2 collapsed following the initial impacts of the aircraft and why and how WTC 7 collapsed;

2. Determine why the injuries and fatalities were so high or low depending on location, including all technical aspects of fire protection, occupant behavior, evacuation, and emergency response;

3. Determine what procedures and practices were used in the design, construction, operation, and maintenance of WTC 1,2, and 7; and

4. Identify, as specifically as possible, areas in current building and fire codes, standards, and practices that warrant revision. 
NIST is a nonregulatory agency of the U.S. Department of Commerce's Technology Administration. The purpose of NIST investigations is to improve the safety and structural integrity of buildings in the United States, and the focus is on fact finding. NIST investigative teams are authorized to assess building performance and emergency response and evacuation procedures in the wake of any building failure that has resulted in substantial loss of life or that posed significant potential of substantial loss of life. NIST does not have the statutory authority to make findings of fault nor negligence by individuals or organizations. Further, no part of any report resulting from a NIST investigation into a building failure or from an investigation under the National Construction Safety Team Act may be used in any suit or action for damages arising out of any matter mentioned in such report (15 USC 281a, as amended by Public Law 107-231).

\section{Organization of the Investigation}

The National Construction Safety Team for this Investigation, appointed by the then NIST Director, Dr. Arden L. Bement, Jr., was led by Dr. S. Shyam Sunder. Dr. William L. Grosshandler served as Associate Lead Investigator, Mr. Stephen A. Cauffman served as Program Manager for Administration, and Mr. Harold E. Nelson served on the team as a private sector expert. The Investigation included eight interdependent projects whose leaders comprised the remainder of the team. A detailed description of each of these eight projects is available at http:/wtc.nist.gov. The purpose of each project is summarized in Table $\mathrm{P}-1$, and the key interdependencies among the projects are illustrated in Fig. $\mathrm{P}-1$.

Table P-1. Federal building and fire safety investigation of the WTC disaster.

Technical Area and Project Leader

Analysis of Building and Fire Codes and Practices; Project Leaders: Dr. H. S. Lew and Mr. Richard W. Bukowski

Baseline Structural Performance and Aircraft Impact Damage Analysis; Project Leader: Dr. Fahim H. Sadek

Mechanical and Metallurgical Analysis of Structural Steel; Project Leader: Dr. Frank W. Gayle

Investigation of Active Fire Protection Systems; Project Leader: Dr. David D. Evans; Dr. William Grosshandler

Reconstruction of Thermal and Tenability Environment; Project Leader: Dr. Richard G. Gann

Structural Fire Response and Collapse Analysis; Project Leaders: Dr. John L. Gross and Dr. Therese P. McAllister

Occupant Behavior, Egress, and Emergency Communications; Project Leader: Mr. Jason D. Averill

Emergency Response Technologies and Guidelines; Project Leader: Mr. J. Randall Lawson

\section{Project Purpose}

Document and analyze the code provisions, procedures, and practices used in the design, construction, operation, and maintenance of the structural, passive fire protection, and emergency access and evacuation systems of WTC 1,2 , and 7.

Analyze the baseline performance of WTC 1 and WTC 2 under design, service, and abnormal loads, and aircraft impact damage on the structural, fire protection, and egress systems.

Determine and analyze the mechanical and metallurgical properties and quality of steel, weldments, and connections from steel recovered from WTC 1,2 , and 7 .

Investigate the performance of the active fire protection systems in WTC 1,2, and 7 and their role in fire control, emergency response, and fate of occupants and responders.

Reconstruct the time-evolving temperature, thermal environment, and smoke movement in WTC 1,2, and 7 for use in evaluating the structural performance of the buildings and behavior and fate of occupants and responders.

Analyze the response of the WTC towers to fires with and without aircraft damage, the response of WTC 7 in fires, the performance of composite steel-trussed floor systems, and determine the most probable structural collapse sequence for WTC 1,2 , and 7 .

Analyze the behavior and fate of occupants and responders, both those who survived and those who did not, and the performance of the evacuation system.

Document the activities of the emergency responders from the time of the terrorist attacks on WTC 1 and WTC 2 until the collapse of WTC 7, including practices followed and technologies used. 


\section{NIST WTC Investigation Projects}

wrc Bulling

Performance steu w

Recommendations

Covemment

Indrotiz:

Protessionat.

Acadenis hoptes

Public Inpuits

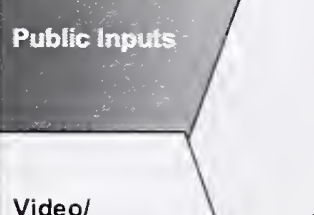

Videol

Photographic

Records

Oral History Data

Emergency

Response

Records

Recovered

Structural Steel

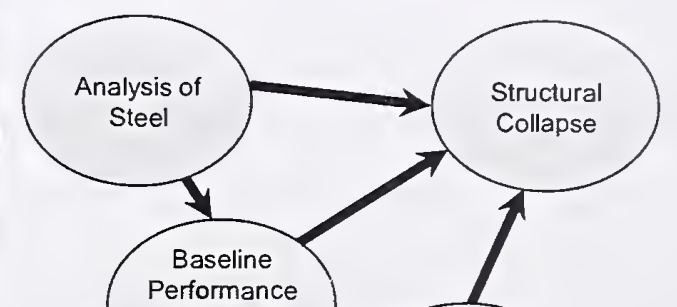

NLT

Evacuation

Figure P-1. The eight projects in the federal building and fire safety investigation of the WTC disaster.

\section{National Construction Safety Team Advisory Committee}

The NIST Director also established an advisory committee as mandated under the National Construction Safety Team Act. The initial members of the committee were appointed following a public solicitation. These were:

- Paul Fitzgerald, Executive Vice President (retired) FM Global, National Construction Safety Team Advisory Committee Chair

- John Barsom, President, Barsom Consulting, Ltd.

- John Bryan, Professor Emeritus, University of Maryland

- David Collins, President, The Preview Group, Inc.

- Glenn Corbett, Professor, John Jay College of Criminal Justice

- Philip DiNenno, President, Hughes Associates, Inc. 
- Robert Hanson, Professor Emeritus, University of Michigan

- Charles Thornton, Co-Chairman and Managing Principal, The Thornton-Tomasetti Group, Inc.

- Kathleen Tierney, Director, Natural Hazards Research and Applications Information Center, University of Colorado at Boulder

- Forman Williams, Director, Center for Energy Research, University of California at San Diego

This National Construction Safety Team Advisory Committee provided technical advice during the Investigation and commentary on drafts of the Investigation reports prior to their public release. NIST has benefited from the work of many people in the preparation of these reports, including the National Construction Safety Team Advisory Committee. The content of the reports and recommendations, however, are solely the responsibility of NIST.

\section{Public Outreach}

During the course of this Investigation, NIST held public briefings and meetings (listed in Table P-2) to solicit input from the public, present preliminary findings, and obtain comments on the direction and progress of the Investigation from the public and the Advisory Committee.

NIST maintained a publicly accessible Web site during this Investigation at http://wtc.nist.gov. The site contained extensive information on the background and progress of the Investigation.

\section{NIST's WTC Public-Private Response Plan}

The collapse of the WTC buildings has led to broad reexamination of how tall buildings are designed, constructed, maintained, and used, especially with regard to major events such as fires, natural disasters, and terrorist attacks. Reflecting the enhanced interest in effecting necessary change, NIST, with support from Congress and the Administration, has put in place a program, the goal of which is to develop and implement the standards, technology, and practices needed for cost-effective improvements to the safety and security of buildings and building occupants, including evacuation, emergency response procedures, and threat mitigation.

The strategy to meet this goal is a three-part NIST-led public-private response program that includes:-

- A federal building and fire safety investigation to study the most probable factors that contributed to post-aircraft impact collapse of the WTC towers and the 47-story WTC 7 building, and the associated evacuation and emergency response experience.

- A research and development (R\&D) program to (a) facilitate the implementation of recommendations resulting from the WTC Investigation, and (b) provide the technical basis for cost-effective improvements to national building and fire codes, standards, and practices that enhance the safety of buildings, their occupants, and emergency responders. 
Table P-2. Public meetings and briefings of the WTC Investigation.

\begin{tabular}{|c|c|c|}
\hline Date & Location & Principal Agenda \\
\hline June 24,2002 & New York City, NY & $\begin{array}{l}\text { Public meeting: Public comments on the Draft Plan for the } \\
\text { pending WTC lnvestigation. }\end{array}$ \\
\hline August 21, 2002 & Gaithersburg, MD & Media briefing announcing the formal start of the Investigation. \\
\hline December 9,2002 & Washington, DC & $\begin{array}{l}\text { Media briefing on release of the Public Update and NIST request } \\
\text { for photographs and videos. }\end{array}$ \\
\hline April 8, 2003 & New York City, NY & $\begin{array}{l}\text { Joint public forum with Columbia University on first-person } \\
\text { interviews. }\end{array}$ \\
\hline April 29-30, 2003 & Gaithersburg, MD & $\begin{array}{l}\text { NCST Advisory Committee meeting on plan for and progress on } \\
\text { WTC lnvestigation with a public comment session. }\end{array}$ \\
\hline May 7,2003 & New York City, NY & Media briefing on release of May 2003 Progress Report. \\
\hline August $26-27,2003$ & Gaithersburg, MD & $\begin{array}{l}\text { NCST Advisory Committee meeting on status of the WTC } \\
\text { investigation with a public comment session. }\end{array}$ \\
\hline September 17, 2003 & New York City, NY & $\begin{array}{l}\text { Media and public briefing on initiation of first-person data } \\
\text { collection projects. }\end{array}$ \\
\hline December 2-3, 2003 & Gaithersburg, MD & $\begin{array}{l}\text { NCST Advisory Committee meeting on status and initial results } \\
\text { and release of the Public Update with a public comment session. }\end{array}$ \\
\hline February 12,2004 & New York City, NY & $\begin{array}{l}\text { Public meeting on progress and preliminary findings with public } \\
\text { comments on issues to be considered in formulating final } \\
\text { recommendations. }\end{array}$ \\
\hline June 18,2004 & New York City, NY & Media/public briefing on release of June 2004 Progress Report. \\
\hline June 22-23, 2004 & Gaithersburg, MD & $\begin{array}{l}\text { NCST Advisory Committee meeting on the status of and } \\
\text { preliminary findings from the WTC Investigation with a public } \\
\text { comment session. }\end{array}$ \\
\hline August 24,2004 & Northbrook, $1 \mathrm{~L}$ & $\begin{array}{l}\text { Public viewing of standard fire resistance test of WTC floor } \\
\text { system at Underwriters Laboratories, lnc. }\end{array}$ \\
\hline October 19-20,2004 & Gaithersburg, MD & $\begin{array}{l}\text { NCST Advisory Committee meeting on status and near complete } \\
\text { set of preliminary findings with a public comment session. }\end{array}$ \\
\hline November 22, 2004 & Gaithersburg, MD & $\begin{array}{l}\text { NCST Advisory Committee discussion on draft annual report to } \\
\text { Congress, a public comment session, and a closed session to } \\
\text { discuss pre-draft recommendations for WTC Investigation. }\end{array}$ \\
\hline April 5, 2005 & New York City, NY & $\begin{array}{l}\text { Media and public briefing on release of the probable collapse } \\
\text { sequence for the WTC towers and draft reports for the projects on } \\
\text { codes and practices, evacuation, and emergency response. }\end{array}$ \\
\hline June 23,2005 & New York City, NY & $\begin{array}{l}\text { Media and public briefing on release of all draft reports for the } \\
\text { WTC towers and draft recommendations for public comment. }\end{array}$ \\
\hline $\begin{array}{l}\text { September 12-13, } \\
2005\end{array}$ & Gaithersburg, MD & $\begin{array}{l}\text { NCST Advisory Committee meeting on disposition of public } \\
\text { comments and update to draft reports for the WTC towers. }\end{array}$ \\
\hline $\begin{array}{l}\text { September } 13-15 \\
2005\end{array}$ & Gaithersburg, MD & $\begin{array}{l}\text { WTC Technical Conference for stakeholders and technical } \\
\text { community for dissemination of findings and recommendations } \\
\text { and opportunity for public to make technical comments. }\end{array}$ \\
\hline
\end{tabular}

- A dissemination and technical assistance program (DTAP) to (a) engage leaders of the construction and building community in ensuring timely adoption and widespread use of proposed changes to practices, standards, and codes resulting from the WTC Investigation and the R\&D program, and (b) provide practical guidance and tools to better prepare facility owners, contractors, architects, engineers, emergency responders, and regulatory authorities to respond to future disasters.

The desired outcomes are to make buildings, occupants, and first responders safer in future disaster events. 


\section{National Construction Safety Team Reports on the WTC Investigation}

A final report on the collapse of the WTC towers is being issued as NIST NCSTAR 1. A companion report on the collapse of WTC 7 is being issued as NIST NCSTAR 1A. The present report is one of a set that provides more detailed documentation of the Investigation findings and the means by which these technical results were achieved. As such, it is part of the archival record of this Investigation. The titles of the full set of Investigation publications are:

NIST (National Institute of Standards and Technology). 2005. Federal Building and Fire Safety Investigation of the World Trade Center Disaster: Final Report on the Collapse of the World Trade Center Towers. NIST NCSTAR 1. Gaithersburg, MD, September.

NIST (National Institute of Standards and Technology). 2006. Federal Building and Fire Safety Investigation of the World Trade Center Disaster: Final Report on the Collapse of World Trade Center 7. NIST NCSTAR 1A. Gaithersburg, MD.

Lew, H. S., R. W. Bukowski, and N. J. Carino. 2005. Federal Building and Fire Safety Investigation of the World Trade Center Disaster: Design, Construction, and Maintenance of Structural and Life Safety Systems. NIST NCSTAR 1-1. National Institute of Standards and Technology. Gaithersburg, MD, September.

Fanella, D. A., A. T. Derecho, and S. K. Ghosh. 2005. Federal Building and Fire Safety Investigation of the World Trade Center Disaster: Design and Construction of Structural Systems. NIST NCSTAR 1-1A. National Institute of Standards and Technology. Gaithersburg, MD, September.

Ghosh, S. K., and X. Liang. 2005. Federal Building and Fire Safety Investigation of the World Trade Center Disaster: Comparison of Building Code Structural Requirements. NIST NCSTAR 1-1B. National Institute of Standards and Technology. Gaithersburg, MD, September.

Fanella, D. A., A. T. Derecho, and S. K. Ghosh. 2005. Federal Building and Fire Safety Investigation of the World Trade Center Disaster: Maintenance and Modifications to Structural Systems. NIST NCSTAR 1-1C. National Institute of Standards and Technology. Gaithersburg, MD, September.

Grill, R. A., and D. A. Johnson. 2005. Federal Building and Fire Safety Investigation of the World Trade Center Disaster: Fire Protection and Life Safety Provisions Applied to the Design and Construction of World Trade Center 1, 2, and 7 and Post-Construction Provisions Applied after Occupancy. NIST NCSTAR 1-1D. National Institute of Standards and Technology. Gaithersburg, $\mathrm{MD}$, September.

Razza, J. C., and R. A. Grill. 2005. Federal Building and Fire Safety Investigation of the World Trade Center Disaster: Comparison of Codes, Standards, and Practices in Use at the Time of the Design and Construction of World Trade Center 1, 2, and 7. NIST NCSTAR 1-1E. National Institute of Standards and Technology. Gaithersburg, MD, September.

Grill, R. A., D. A. Johnson, and D. A. Fanella. 2005. Federal Building and Fire Safety Investigation of the World Trade Center Disaster: Comparison of the 1968 and Current (2003) New 
York City Building Code Provisions. NIST NCSTAR 1-1F. National Institute of Standards and Technology. Gaithersburg, MD, September.

Grill, R. A., and D. A. Johnson. 2005. Federal Building and Fire Safety Investigation of the World Trade Center Disaster: Amendments to the Fire Protection and Life Safety Provisions of the New York City Building Code by Local Laws Adopted While World Trade Center 1, 2, and 7 Were in Use. NIST NCSTAR 1-1G. National Institute of Standards and Technology. Gaithersburg, MD, September.

Grill, R. A., and D. A. Johnson. 2005. Federal Building and Fire Safety Investigation of the World Trade Center Disaster: Post-Construction Modifications to Fire Protection and Life Safety Systems of World Trade Center 1 and 2. NIST NCSTAR 1-1H. National Institute of Standards and Technology. Gaithersburg, MD, September.

Grill, R. A., D. A. Johnson, and D. A. Fanella. 2005. Federal Building and Fire Safety Investigation of the World Trade Center Disaster: Post-Construction Modifications to Fire Protection, Life Safety, and Structural Systems of World Trade Center 7. NIST NCSTAR 1-11. National Institute of Standards and Technology. Gaithersburg, MD, September.

Grill, R. A., and D. A. Johnson. 2005. Federal Building and Fire Safety Investigation of the World Trade Center Disaster: Design, Installation, and Operation of Fuel System for Emergency Power in World Trade Center 7. NIST NCSTAR 1-1 J. National Institute of Standards and Technology. Gaithersburg, MD, September.

Sadek, F. 2005. Federal Building and Fire Safety Investigation of the World Trade Center Disaster: Baseline Structural Performance and Aircraft Impact Damage Analysis of the World Trade Center Towers. NIST NCSTAR 1-2. National Institute of Standards and Technology. Gaithersburg, MD, September.

Faschan, W. J., and R. B. Garlock. 2005. Federal Building and Fire Safety Investigation of the World Trade Center Disaster: Reference Structural Models and Baseline Performance Analysis of the World Trade Center Towers. NIST NCSTAR 1-2A. National Institute of Standards and Technology. Gaithersburg, MD, September.

Kirkpatrick, S. W., R. T. Bocchieri, F. Sadek, R. A. MacNeill, S. Holmes, B. D. Peterson, R. W. Cilke, C. Navarro. 2005. Federal Building and Fire Safety Investigation of the World Trade Center Disaster: Analysis of Aircraft Impacts into the World Trade Center Towers, NIST NCSTAR 1-2B. National Institute of Standards and Technology. Gaithersburg, MD, September.

Gayle, F. W., R. J. Fields, W. E. Luecke, S. W. Banovic, T. Foecke, C. N. McCowan, T. A. Siewert, and J. D. McColskey. 2005. Federal Building and Fire Safety Investigation of the World Trade Center Disaster: Mechanical and Metallurgical Analysis of Structural Steel. NIST NCSTAR 1-3. National Institute of Standards and Technology. Gaithersburg, MD, September.

Luecke, W. E., T. A. Siewert, and F. W. Gayle. 2005. Federal Building and Fire Safety Investigation of the World Trade Center Disaster: Contemporaneous Structural Steel Specifications. NIST Special Publication 1-3A. National Institute of Standards and Technology. Gaithersburg, MD, September. 
Banovic, S. W. 2005. Federal Building and Fire Safety Investigation of the World Trade Center Disaster: Steel Inventory and Identification. NIST NCSTAR 1-3B. National Institute of Standards and Technology. Gaithersburg, MD, September.

Banovic, S. W., and T. Foecke. 2005. Federal Building and Fire Safety Investigation of the World Trade Center Disaster: Damage and Failure Modes of Structural Steel Components. NIST NCSTAR 1-3C. National Institute of Standards and Technology. Gaithersburg, MD, September.

Luecke, W. E., J. D. McColskey, C. N. McCowan, S. W. Banovic, R. J. Fields, T. Foecke, T. A. Siewert, and F. W. Gayle. 2005. Federal Building and Fire Safety Investigation of the World Trade Center Disaster: Mechanical Properties of Structural Steels. NIST NCSTAR 1-3D. National Institute of Standards and Technology. Gaithersburg, MD, September.

Banovic, S. W., C. N. McCowan, and W. E. Luecke. 2005. Federal Building and Fire Safety Investigation of the World Trade Center Disaster: Plysical Properties of Structural Steels. NIST NCSTAR 1-3E. National Institute of Standards and Technology. Gaithersburg, MD, September.

Evans, D. D., R. D. Peacock, E. D. Kuligowski, W. S. Dols, and W. L. Grosshandler. 2005. Federal Building alnd Fire Safety Investigation of the World Trade Center Disaster: Active Fire Protection Systems. NIST NCSTAR 1-4. National Institute of Standards and Technology. Gaithersburg, MD, September.

Kuligowski, E. D., D. D. Evans, and R. D. Peacock. 2005. Federal Building and Fire Safety Investigation of the World Trade Center Disaster: Post-Construction Fires Prior to September 11, 2001. NIST NCSTAR 1-4A. National Institute of Standards and Technology. Gaithersburg, MD, September.

Hopkins, M., J. Schoenrock, and E. Budnick. 2005. Federal Building and Fire Safety Investigation of the World Trade Center Disaster: Fire Suppression Systens. NIST NCSTAR 1-4B. National Institute of Standards and Technology. Gaithersburg, MD, September.

Keough, R. J., and R. A. Grill. 2005. Federal Building and Fire Safety Investigation of the World Trade Center Disaster: Fire Alarm Systems. NIST NCSTAR 1-4C. National Institute of Standards and Technology. Gaithersburg, MD, September.

Ferreira, M. J., and S. M. Strege. 2005. Federal Building and Fire Safety Investigation of the World Trade Center Disaster: Smoke Management Systems. NIST NCSTAR 1-4D. National Institute of Standards and Technology. Gaithersburg, MD, September.

Gann, R. G., A. Hamins, K. B. McGrattan, G. W. Mulholland, H. E. Nelson, T. J. Ohlemiller, W. M. Pitts, and K. R. Prasad. 2005. Federal Building and Fire Safety Investigation of the World Trade Center Disaster: Reconstruction of the Fires in the World Trade Center Towers. NIST NCSTAR 1-5. National Institute of Standards and Technology. Gaithersburg, MD, September.

Pitts, W. M., K. M. Butler, and V. Junker. 2005. Federal Building and Fire Safety Investigation of the World Trade Center Disaster: Visual Evidence, Damage Estimates, and Timeline Analysis. NIST NCSTAR 1-5A. National Institute of Standards and Technology. Gaithersburg, MD, September. 
Hamins, A., A. Maranghides, K. B. McGrattan, E. Johnsson, T. J. Ohlemiller, M. Donnelly, J. Yang, G. Mulholland, K. R. Prasad, S. Kukuck, R. Anleitner and T. McAllister. 2005. Federal Building and Fire Safety Investigation of the World Trade Center Disaster: Experiments and Modeling of Structural Steel Elements Exposed to Fire. NIST NCSTAR 1-5B. National Institute of Standards and Technology. Gaithersburg, MD, September.

Ohlemiller, T. J., G. W. Mulholland, A. Maranghides, J. J. Filliben, and R. G. Gann. 2005. Federal Building and Fire Safety Investigation of the World Trade Center Disaster: Fire Tests of Single Office Workstations. NIST NCSTAR 1-5C. National Institute of Standards and Technology. Gaithersburg, MD, September.

Gann, R. G., M. A. Riley, J. M. Repp, A. S. Whittaker, A. M. Reinhorn, and P. A. Hough. 2005. Federal Building and Fire Safety Investigation of the World Trade Center Disaster: Reaction of Ceiling Tile Systems to Shocks. NIST NCSTAR 1-5D. National Institute of Standards and Technology. Gaithersburg, MD, September.

Hamins, A., A. Maranghides, K. B. McGrattan, T. J. Ohlemiller, and R. Anleitner. 2005. Federal Building and Fire Safety Investigation of the World Trade Center Disaster: Experiments and Modeling of Multiple Workstations Burning in a Compartment. NIST NCSTAR 1-5E. National Institute of Standards and Technology. Gaithersburg, MD, September.

McGrattan, K. B., C. Bouldin, and G. Forney. 2005. Federal Building and Fire Safety Investigation of the World Trade Center Disaster: Computer Simulation of the Fires in the World Trade Center Towers. NIST NCSTAR 1-5F. National Institute of Standards and Technology. Gaithersburg, MD, September.

Prasad, K. R., and H. R. Baum. 2005. Federal Building and Fire Safety Investigation of the World Trade Center Disaster: Fire Structure Interface and Thermal Response of the World Trade Center Towers. NIST NCSTAR 1-5G. National Institute of Standards and Technology. Gaithersburg, $\mathrm{MD}$, September.

Gross, J. L., and T. McAllister. 2005. Federal Building and Fire Safety Investigation of the World Trade Center Disaster: Structural Fire Response and Probable Collapse Sequence of the World Trade Center Towers. NIST NCSTAR 1-6. National Institute of Standards and Technology. Gaithersburg, MD. September.

Carino, N. J., M. A. Starnes, J. L. Gross, J. C. Yang, S. Kukuck, K. R. Prasad, and R. W. Bukowski. 2005. Federal Building and Fire Safety Investigation of the World Trade Center Disaster: Passive Fire Protection. NIST NCSTAR 1-6A. National Institute of Standards and Technology. Gaithersburg, MD, September.

Gross, J., F. Hervey, M. Izydorek, J. Mammoser, and J. Treadway. 2005. Federal Building and Fire Safety Investigation of the World Trade Center Disaster: Fire Resistance Tests of Floor Truss Systens. NIST NCSTAR 1-6B. National Institute of Standards and Technology. Gaithersburg, $\mathrm{MD}$, September.

Zarghamee, M. S., S. Bolourchi, D. W. Eggers, Ö. O. Erbay, F. W. Kan, Y. Kitane, A. A. Liepins, M. Mudlock, W. I. Naguib, R. P. Ojdrovic, A. T. Sarawit, P. R Barrett, J. L. Gross, and 
T. P. McAllister. 2005. Federal Building and Fire Safety Investigation of the World Trade Center Disaster: Component, Connection, and Subsystem Structural Analysis. NIST NCSTAR 1-6C. National Institute of Standards and Technology. Gaithersburg, MD, September.

Zarghamee, M. S., Y. Kitane, Ö. O. Erbay, T. P. McAllister, and J. L. Gross. 2005. Federal Building and Fire Safety Investigation of the World Trade Center Disaster: Global Strnctural Analysis of the Response of the World Trade Center Towers to Impact Damage and Fire. NIST NCSTAR 1-6D. National Institute of Standards and Technology. Gaithersburg, MD, September.

McAllister, T., R. W. Bukowski, R. G. Gann, J. L. Gross, K. B. McGrattan, H. E. Nelson, L. Phan, W. M. Pitts, K. R. Prasad, F. Sadek. 2006. Federal Building and Fire Safety Investigation of the World Trade Center Disaster: Structural Fire Response and Probable Collapse Sequence of World Trade Center 7. (Provisional). NIST NCSTAR 1-6E. National Institute of Standards and Technology. Gaithersburg, MD.

Gilsanz, R., V. Arbitrio, C. Anders, D. Chlebus, K. Ezzeldin, W. Guo, P. Moloney, A. Montalva, J. Oh, K. Rubenacker. 2006. Federal Building and Fire Safety Investigation of the World Trade Center Disaster: Structural Analysis of the Response of World Trade Center 7 to Debris Damage and Fire. (Provisional). NIST NCSTAR 1-6F. National Institute of Standards and Technology. Gaithersburg, MD.

Kim, W. 2006. Federal Building and Fire Safety Investigation of the World Trade Center Disaster: Analys is of September 11, 2001, Seismogram Data. (Provisional). NIST NCSTAR 1-6G. National Institute of Standards and Technology. Gaithersburg, MD.

Nelson, K. 2006. Federal Building and Fire Safety Investigation of the World Trade Center Disaster: The Con Ed Substation in World Trade Center 7. (Provisional). NIST NCSTAR 1-6H. National Institute of Standards and Technology. Gaithersburg, MD.

Averill, J. D., D. S. Mileti, R. D. Peacock, E. D. Kuligowski, N. Groner, G. Proulx, P. A. Reneke, and H. E. Nelson. 2005. Federal Building and Fire Safety Investigation of the World Trade Center Disaster: Occupant Behavior, Egress, and Emergency Commmication. NIST NCSTAR 1-7. National Institute of Standards and Technology. Gaithersburg, MD, September.

Fahy, R., and G. Proulx. 2005. Federal Building and Fire Safety Investigation of the World Trade Center Disaster: Analys is of Published Accounts of the World Trade Center Evacuation. NIST NCSTAR 1-7A. National Institute of Standards and Technology. Gaithersburg, MD, September.

Zmud, J. 2005. Federal Building and Fire Safety Investigation of the World Trade Center Disaster: Technical Documentation for Survey Administration. NIST NCSTAR 1-7B. National Institute of Standards and Technology. Gaithersburg, MD, September.

Lawson, J. R., and R. L. Vettori. 2005. Federal Building and Fire Safety Investigation of the World Trade Center Disaster: The Emergency Response Operations. NIST NCSTAR 1-8. National Institute of Standards and Technology. Gaithersburg, MD, September. 


\section{Section I}

\section{PANYNJ Guidelines for Inspection, Repair, and Modifications to Fire Protection Systems}


This page intentionally left blank. 


\section{EXECUTIVE SUMMARY}

As part of the analysis of building and fire codes and standards of the National Institute of Standards and Technology World Trade Center (WTC) Investigation, this report supports the effort to document the Port Authority of New York and New Jersey (PANYNJ) guidelines for inspection, repair, and modifications to the fire protection systems in the WTC. Over the life of the buildings, in particular WTC 1, 2, and 7, repairs and modifications were made. These changes, depending on the magnitude of the enhancement, may have affected the overall building performance. The purpose of this report is to document the PANYNJ guidelines for inspection, repair, and modifications to fire protection and egress systems in WTC 1, 2, and 7. These include guidelines governing the inspection and upgrading of fire alarm and fire suppression systems, the reapplication of fireproofing, and the upgrading of elevators, hoistways, and elevator lobbies.

As part of the document search for this report, manuals, program standards, surveys, and correspondence of many parties were reviewed and analyzed. The following sections provide a summary of the documents that include guidelines and procedures for maintaining and modifying the fire protection and egress systems of the WTC.

\section{Memorandums of Understanding}

The PANYNJ, not being technically subject to the local building code of New York City, created a Memorandum of Understanding (MOU) with the New York City Department of Buildings (NYCDB) in 1993 to establish procedures and avoid construction conflicts. The MOU ensured that any construction project performed by the PANYNJ or any tenant within a PANYNJ building in New York City would conform to the Building Code of the City of New York (BCNYC). The MOU gave the PANYNJ the right to approve building plans. Any variance to the BCNYC, permitted by the PANYNJ, would be sent to the NYCDB for review.

In June of 1995 , a supplement to the PANYNJ/NYCDB MOU was added. The MOU supplement permitted PANYNJ tenants to use New York State licensed engineers/architects to self certify construction plans and certify that the installation was in accordance to the certified plans, provided the engineers/architects meets the qualifications established by PANYNJ. The person approving the construction plans could not be the same person certifying that the installation was in accordance with the approved plans until September of 1995, when another supplement was added. The September 1995 supplement permitted a single New York State licensed engineer/architect to certify the construction plans and the installation.

In 1993, a MOU with the PANYNJ and the New York City Fire Department (FDNY) was established. The MOU permitted the FDNY to conduct fire safety inspections at the PANYNJ facilities in New York City. Upon inspection, the findings and recommendations were sent to PANYNJ for review and corrective action if necessary. In 1995, an amendment to the MOU was adopted requiring written notice to the FDNY of any additions or modifications to existing fire safety systems. The amendment also required the design and review of the addition or modification to be performed by a New York State 
licensed engineer or architect. Additionally, the amendment required the design and review of such design to be performed by separate individuals.

\section{Tenant Construction Review Manuals}

The Tenant Construction Review Manuals were created by the Engineering Department, Quality Assurance Division of PANYNJ. The manuals were created to establish technical criteria to be followed by the tenants and their architectural and engineering consultants. Manuals were available from 1971 to 1997. The manuals indicated the applicable codes, standards and PANYNJ criteria that would be used to determine compliance of each modification or addition.

\section{Design Guidelines}

Various design guidelines were created by PANYNJ. Design guidelines were created for all the major construction disciplines. The design guidelines included minimum specifications and standard details for use in the alteration projects throughout the WTC complex. Details pertaining to standpipe systems, fire sprinkler systems, fire alarm systems, fireproofing and egress requirements were included.

\section{Operation and Maintenance Manuals}

The Engineering Department of PANYNJ established Operation and Maintenance Mamuals (34 total) for the various systems throughout the WTC. Each manual contains Maintenance Procedure Cards describing in detail the inspection and maintenance procedures for the work to be done, including the frequency of each test or maintenance. Manuals \#13, \#18, and \#23 describe the details for the fire sprinkler, standpipe and special hazard systems. Manual \#23 and \#12 provides the procedures for the inspection and maintenance of the fire detection systems.

\section{Port Authority Facility Condition Survey Program}

A facility condition survey program was established to continually monitor the condition of the WTC buildings. Engineering firms were contracted by PANYNJ to perform detailed inspections of the building conditions. Various building components, including architectural and structural, were inspected, photos were taken, and reports were generated with recommendations and guidelines for repair or replacement as necessary. There are at least two reports that detail the inspection and testing of fireproofing materials.

\section{Structural Integrity Testing and Inspection Program}

The Structural Integrity Testing and Inspection Program was established by the PANYNJ Engineering Department and Leslie E. Robertson Associates to monitor the structural integrity of WTC 1 and WTC 2. Although the complete details of this program are not summarized in this report, important procedures for the repair of fire proofing material are discussed. It was recommended to repair fire proofing material with the same brand and type initially used, where practical. Additional procedures were given based on the size of area being repaired and brand of material identified. 


\section{Tenants Manual}

In 1984, the World Trade Center Tenants Manual was devcloped to provide WTC tenants information regarding the functions of the Operations Division of WTC. By following building standard requirements, the Opcrations Division could bc contracted by a tcnant to make alterations without having to hire an outside contractor or go through the rcview process with the WTC Planning Department.

\section{Other Documents}

As part of each tenant modification, specifications were created to establish minimum requirements as required by codes. There were literally hundreds of tenant alterations performed in WTC 1, 2, and 7. Summaries of the alterations on the affected floors of WTC 1 and WTC 2 and all of the alterations in WTC 7 are contained in a separate report. However, a specification to replace fireproofing matcrial on the exposed columns and beams within the elevator shaft of WTC 1 identified additional procedures used at the WTC. This is discussed in Chapter 9 of this report. This specification listed the performance criteria, testing, and inspection requirements for fire proofing material. 
This page intentionally left blank. 


\section{Chapter 1 \\ INTRODUCTION}

Over the course of years, the World Trade Center (WTC) complex and surrounding buildings were altered for numerous reasons, including tenant alterations, inspections, building repairs, enhancement, and maintenance. As changes occurred, the need to maintain safety standards arose. The Port Authority of New York and New Jersey (PANYNJ) adopted policies that set forth procedures to maintain and enhance safety standards at PANYNJ facilities. The purpose of this report is to document the PANYNJ guidelines for inspection, repair, and modifications to fire protection and egress systems in WTC 1,2, and 7. These include guidelines governed the inspection and upgrading of fire alarm and fire suppression systems, the reapplication of fireproofing, and the upgrading of elevators, hoistways, and elevator lobbies.

The guidelines and policies are found in many PANYNJ documents and involved many parties. Manuals, program standards, surveys, and correspondence have been reviewed and analyzed in an effort to summarize the modification guidelines. Documents containing important information used in the process of performing building modifications are summarized in the following sections. 
This page intentionally left blank. 


\section{Chapter 2 \\ MEMORANDUMS OF UNDERSTANDING}

The facilities of the Port Authority of New York and New Jersey (PANYNJ or Port Authority), an interstate compact under the U.S. Constitution, are not technically subject to the requirements of the local building codes, although PANYNJ intended to voluntarily follow the New York City codes where applicable. In order to minimize conflicts betwcen PANYNJ and the New York City requirements for the World Trade Center (WTC), Memorandums of Understanding (MOUs) were executed. One MOU was executed between PANYNJ and the New York City Department of Buildings (NYCDB) in 1993 (PANYNJ 1993a). Another MOU was executed between PANYNJ and the New York City Fire Department (FDNY) also in 1993 (PANYNJ 1993b).

In November 1993, an agreement between PANYNJ and NYCDB was executed to establish procedures and ensure that any construction project of the PANYNJ or any of its tenants at buildings owned or operated by PANYNJ located in New York City conform to the Building Code of the City of New York (BCNYC).

Under the agreement to ensure conformance with the standards set forth in the Code at the time of design, the parties agreed that the design and review of such systems be performed by New York State licensed architects and engineers. Also, the New York State licensed architect and/or engineer approving the plans for any addition or modification for the Port Authority may not have assisted in the preparation of such plans. The Port Authority agreed to have each tenant obtain a certification from a New York State licensed architect or engineer that such system was constructed in accordance with the approved plans and specifications. For systems effectuated by the Port Authority, the Chief Engineer or his successor in duties was to certify that the system was constructed in accordance with the approved plans and specifications. The Port Authority was to maintain a file for each project, which would contain the most current documents, including certifications, necessary to justify code conformance. NYCDB was permitted, to at any time, request the Port Authority to provide NYCDB with a copy of any fire safety file. Any variance with the codes approved by the Chief Engineer of PANYNJ was to be sent to NYCDB. If NYCDB disagreed with the variance, NYCDB was to advise PANYNJ. Any matters of code conformance not resolved were subject to further review of PANYNJ Board of Commissioners. The MOU also indicates that PANYNJ would continue to conduct or cause to be conducted all building inspections, during both construction and post-construction periods. PANYNJ is to continue to perform structural integrity inspections on a cyclical basis for all of its structures located in New York City.

In June 1995, a supplement was added to the PANYNJ/NYCDB MOU. NYCDB had instituted an optional plan review system since the execution of the original MOU. The supplement requires WTC tenants to utilize New York State licensed architects or engineers meeting qualifications established by PANYNJ to certify and review projects, in lieu of any review by the Port Authority. It also states that the person who reviews and certifies the construction plans for code conformance cannot be the same person that certifies that construction has been performed in accordance with the approved plans. 
In September 1995, a change to the supplement of the PANYNJ/NYCDB MOU was executed in connection with the PANYNJ's Tenant Self-Ccrtification Program at the WTC. The change allows a single New York State licensed architect or engineer to certify both the construction plans and that construction is in conformance with the approved plans with the following exception if the alteration changes the character of the occupancy group under paragraph 27-237 of the BCNYC that would have been applicable had such space been located in a privately owned building.

In December 1993, procedures were set forth to implement the existing policy established in April 1993 between PANYNJ and FDNY. The Port Authority agreed to permit FDNY, acting through its Bureau of Fire Prevention (BFP), to conduct fire safety inspections at any PANYNJ facility in New York City. Upon inspection, BFP was to issue a report of fire safety findings and recommendations for corrective action with respect to any deficiencies to the Port Authority's General Manager of Risk Management operations. The Port Authority would undertake the implementation of such findings and corrective actions and notify BFP of the actions taken. BFP also had the right to conduct follow-up inspections with respect to any recommendations to PANYNJ.

In 1995, an Amendment to the PANYNJ/FDNY MOU was executed with respect to additions and/or modifications to existing fire safety systems. The Port Authority was to notify BFP in writing prior to the introduction of any additions or modifications to existing fire safety systems in a PANYNJ facility in the City of New York. BFP agreed to permit PANYNJ to review additions and/or modifications to existing fire safety systems. To ensure conformance with the standards set forth in local codes and regulations, the design and review of such systems were required to be performed by New York State licensed architects and engineers. Also, the New York State licensed, architect and/or engineer approving the plans for any addition or modification was not to have assisted in the actual preparation of such plans. This provision was later modified (September 1995) to permit the same New York State licensed architect or engineer to prepare and certify that plans met current code requirements.

The Port Authority agreed to require each tenant to obtain a certification from a New York State licensed architect or engineer that modifications were constructed in accordance with the approved plans and specifications. For systems effectuated by PANYNJ, the Port Authority Office of Risk Management would certify that the system was constructed in accordance with the approved plans and specifications. PANYNJ would maintain a file for each new or modified system, which would contain the most current documents, including certifications, necessary to justify code conformance. BFP could at any time request PANYNJ to provide BFP with a copy of any fire safety file. BFP could also audit any new or modified fire safety system to ensure conformance with the standards set forth in local codes and regulations. However, when circumstances or conditions were unusual, the Port Authority could petition the BFP for a variance.

Whenever work was done in the WTC buildings, a project number was assigned by the Port Authority under which all contracts, drawings, and correspondence was filed. These numbers are typically of the format W(yy)-1234 (where yy is the year initiated and 1234 is a four-digit number). This report includes these numbers as references to individual projects, and files retained by the Port Authority are identified by these numbers. 


\section{Chapter 3 \\ Tenant Construction ReView Manuals}

The Tenant Construction Review Manual (the Manual) was prepared by the Engineering Department, Quality Assurance Division of the Port Authority of New York and New Jersey (PANYNJ or Port Authority). Manuals were available between 1971 and March 1997. The Manual presents technical criteria to be followed by tenants and their architectural and engineering consultants at all Port Authority facilities, including the World Trade Center (WTC) complex. The following guidelines for inspection, repair, and modifications to fire protection and egress systems are from the March 1997 (latest) cdition of the Manual.

\subsection{GENERAL}

Each chapter or section of the Manual refers to compliance with the applicable codes, standards, and Port Authority design criteria listed in the particular section. The codes and regulations referenced for use in New York City include the following:

1. New York City Building Code and its Reference Standards

2. New York City Fire Prevention Code and Directives

3. New York City Local Laws

4. Rules of the Board of Standards and Appeals

5. New York State Labor Law

6. New York State Multiple Dwelling Law (Hotels)

7. New York State Energy Conservation Construction Code

8. Directives and Memoranda of the Department of Buildings

9. Rules of the City of New York, Title 1, Department of Buildings

10. New York City Electrical Code

11. National Electrical Code

Additionally, tenant modifications at all Port Authority facilities were required to comply with the Americans with Disabilities Act and applicable Flood Controls.

In addition to the Reference Standards referenced in the Building Code of the City of New York (BCNYC), the following standards are specifically referenced: 
1. National Fire Protection Association (NFPA) 75, Computer Rooms

2. NFPA 20, Centrifugal Fire Pumps

3. NFPA 30, Flammable and Combustible Liquids Code

4. NFPA 54, National Fuel Gas Code

5. NFPA Standards in areas not covered by codes

In addition to the Port Authority design criteria, Section 14 of the Manual outlines the requirements for acceptance (approval) of materials, assemblies, forms, methods of construction, and the intended use of equipment, as well as the requirements for inspection of materials, assemblies, and construction. The requirements for the approval/acceptance of materials and equipment and the requirements for controlled inspections are abstracted from the BCNYC.

\section{$3.2 \quad$ FIRE SUPPRESSION}

The guidelines for the installation and alteration of sprinkler and fire suppression systems are included in:

- Section $10-$ Mechanical

- Section 11 - Plumbing

- Section 12 - Fire Protection

Section 10 - Mechanical covers fire suppression systems and controls. For the WTC, the Port Authority Design Criteria refers to the published WTC guidelines for heating, ventilating, and air conditioning and Fire Safety systems (see Design Guidelines below).

Section 11 - Plumbing covers fire sprinklers and standpipes. At the WTC, the Port Authority Design Criteria for plumbing and fire protection work was required to conform to the Tenant Plumbing/Fire Protection Design Guidelines (see Design Guidelines below). Details of the representative fire protection items reviewed by the PANYNJ include:

- Fire standpipe systems: floor plans, riser diagrams and available water pressure.

- Sprinkler/fire protection systems: water supplies, mains, risers, valves, siamese connections, etc., principal construction features of the building, electrical or automatic devices, and hydraulic calculations as required by NFPA 13.

- Other fire suppression systems: plans for chemical or gaseous fire suppression piping systems were required to contain: the type of extinguishing agent and number and size of agent containers, size, length and type of all piping used, number and location of all fusible links or detectors and the temperature setting.

Section 12 - Fire Protection covers the design of various fire detection, alarm and suppression systems. Details of representative fire protection items reviewed by the PANYNJ include: 
- Sprinkler and other systems using dry chemicals, foams, gascous, and other extinguishing agents shall be shown on drawings, signed and scalcd by the Architcet or Engineer of record, or if prepared by a spccialized consultant, signed and sealed by such liccnsed consultant. Said consultants must be licensed to practice in the state in which the work will be performed.

- Sprinkler plans shall indicate or list the appropriate information and data specificd in NFPA 13 regarding available water sources, supply pressure, number and type of sprinklers, fire department connections, hazard classification, alarm dcvices, and supervisory connections. Hydraulic computations shall be submitted when used.

\subsection{FIRE ALARM}

Section 12 - Fire Protection covers the design of various fire detection, alarm and suppression systems. For the WTC complex, the Port Authority Design Criteria includes specific requircments for:

- Wiring: including general, initiating device circuits (smoke and heat detectors, system interfaces and manual pull stations), notification appliance circuits, control circuits and power supply.

- System: All components connected to the WTC Base Building Fire Alarm System were required to be fully compatible with the Base System. Underwriters Laboratories, Inc./Materials and Equipment Acceptance listings, cross listings and manufacturers' approvals were required. Additional requirements include: field circuits, rclay control circuits and conventional inputs (waterflow, tamper, alarm and trouble from tenant panels).

Details of the representative fire protection items reviewed by the PANYNJ include a complete fire alarm riser diagram showing locations of all manual pull stations, visible and audible alerting devices, control panels and wiring where required to be provided.

\section{$3.4 \quad$ FIREPROOFING}

No specific design criteria is specified in Section 5-Architectural, however, the Details of Architectural Review include fire protection of building components and finishes (including documentation verifying that all materials and equipment used are of an approved type).

Section 14 - Materials, Operations and Equipment Approval and Inspection includes the requirements for acceptance (approval) of materials, assemblies, etc. and the requirement for controlled inspections of materials, assemblies and construction.

Spray-on fireproofing, in accordance with BCNYC Sec. 27-345(h), is specifically listed as an item subject to controlled inspection. Such inspection is required to be made and witnessed by or under the direct supervision of a registered architect or professional engineer. 


\subsection{EGRESS}

Section 5 - Architectural covers the scope of the architectural review consisting of compliancc with the applicable codes, standards and PANYNJ design criteria. Other than the referenced codes and regulations, no specific means of egress design criteria is stated.

The Details of Architectural Review in Section 5 include egress, establishing occupant load and existing capacity, including door and hardware requirements.

In addition, Section 10 - Mechanical includes requirements for smoke detectors and fire/smoke dampers at ducts entering "safe areas," exit passageways and lobbies. 


\section{Chapter 4 \\ DESIGN GUIDELINES}

The Port Authority of New York and New Jerscy (PANYNJ or Port Authority) prepared scveral Design Guidelines, Specifications and Standard Details for use in construction and altcrations at the World Tradc Center (WTC) complex. The following guidelines were reviewed for criteria pcrtaining to the maintenance and modifications of fire protection and egress systems:

- Architectural and Structural Design Guidelines, Specifications and Standard Details February 27, 1998.

- Design Guidelines, Specifications and Standard Dctails Program for heating, ventilating, and air conditioning (HVAC), Fire Protcction and Plumbing - Revised May 11, 1998.

- Electrical Design Guidelines, Specifications and Standard Details for Electrical, Communications and Fire Alarm - November 25, 1997.

- Mandated Fire Alarm Guidelines for the WTC Base Building Fire Alarm System Design, Construction, Maintenance and Technical Support Services - March 1999.

The following sections outline the inspection, repair, and modification criteria established for the fire protection and egress systems.

\subsection{GENERAL}

The Design Guidelines were intended to provide design requirements and criteria for tenant alterations at WTC. The design specifications were intended to provide the tenant's consultant engineer with WTC requirements for each of the respective trades. The substance of the specifications was required to be included in the construction documents.

The scope of the architectural and engineering reviews was to ensure compliance with the applicable codes, standards and WTC Design Criteria.

Although the scope of this report does not address compliance with the Americans with Disabilities Act (ADA), several references are made to ADA regarding egress requirements, such as door hardware and access/corridor dimensions and visual warning devises (strobes) connected to the fire alarm system.

\subsection{FIRE SUPPRESSION}

The Design Guidelines, Specifications and Standard Details Program for HVAC, Fire Protection and Plumbing outline the criteria for wet-pipe sprinkler systems, preaction systems, fire standpipe systems, clean agent extinguishing systems, halon fire extinguishing systems and portable fire extinguishers as follows: 


\section{Wet-Pipe Sprinkler Systems}

All tenant spaces were required to be sprinklered. At the time the Design Guidelines were published, most tenant floors in the WTC were provided with wet-pipe sprinkler systems. New tenants normally rcquired a new sprinkler system. For renovations of existing spaces, modifications to the existing system would normally need to comply with any new partition configuration.

Sprinkler work was required to be designed to comply with the requirements of the Building Code of the City of New York (BCNYC), National Fire Protection Association (NFPA) 13 and the PANYNJ design guides. In areas requiring specialized sprinkler systems, additional applicable standards as referenced in NFPA 13 were required to be used for design, including but not limited to the following NFPA 15, 16, 231 , and 231C.

Sprinkler systems were required to be hydraulically designed. A pipe schedule design was only permitted for minor renovations that did not change the number of heads, and where only a few existing sprinkler heads required relocation.

\section{Preaction Systems}

Only a single zone detecting system was required to be used. Actuation of the fire detection system was required to open the preaction valve permitting water to flow into the sprinkler system piping. Sprinkler pipe sizing was required to be hydraulically calculated.

Preaction systems may have been required when wet-pipe sprinkler systems were not provided in computer rooms to protect the areas above the raised floor. As an alternative, a total flooding, clean agent fire extinguishing system was permitted. Areas under raised floors, where wiring was installed in raceways and combustibles are limited, only required smoke detector protection. If the amount of combustibles was extensive, and/or the cabling was not in raceways, these areas were required to be protected by a carbon dioxide system or an approved total flooding, clean agent system.

\section{Fire Standpipe Systems}

In WTC 1 and WTC 2, three fire standpipe risers supplied water to the hose stations on Floors 1 through 110. Risers FS-F1, FS-F2 and FS-F3 were located in Stairway B (Stairway 3), C (Stairway 2), and A (Stairway 1), respectively. Riser FS-F1 supplied water to all hose racks in Stairway B and also to all auxiliary hose cabinets in the corridors and tenant areas.

In WTC 1 and WTC 2, tenant auxiliary standpipe systems were only permitted to be connected to the existing capped outlets provided at fire standpipe riser FS-F1 located in Stairway B.

\section{Clean Agent Fire Extinguishing Systems}

New installations of gas-fired extinguishing systems were permitted in the WTC where the systems were approved by New York City.

Inspection, testing and maintenance of automatic gas systems was required to be performed by competent contractors. Recorded results were required to be submitted to the WTC Fire Safety Coordinator. 
Inspection, testing and maintenance was rcquired to conform to the rccommended routincs outlined in NFPA 2001, the BCNYC, the New York City Fire Department (FDNY) Dircetive reference and the manufacturer's maintenance and servicc manuals.

A separate duct purge system (minimum of 6 air changes per hour of exhaust rate) was required to exhaust the discharging gas to the outdoors. The cxhaust duct was required to be arranged so no gas was allowed to infiltrate into other spaces.

Complete contract drawings, specifications and testing procedures were required to be submitted to the Port Authority for review with the Tenant Alteration Application.

\section{Halon Fire Extinguishing Systems}

New halon fire extinguishing systems were not pcrmitted to be installed in the WTC.

When an existing halon system was to be abandoned, the halon storage containers were to be carefully removed so that halon would not be discharged. Containers were required to be returned for recycling, or recovery of the agent when no longer needed, to comply with NFPA 12A, Sec. 2-1.4.2 (1992 Edition).

If a tenant decided to keep an existing halon fire protection system, the following tasks were required to be performed:

1. Inspection, testing and maintenance of automatic halon systems were required to be performed by competent contractors. Recorded results were required to be submitted to the WTC Fire Safety Coordinator.

2. Inspection, testing and maintenance was required to conform to the recommended routine outlined in NFPA 12A, FDNY Directives (dated October 22, 1990) and the manufacturer's maintenance and service manuals.

3. A complete testing specification was required to be submitted to the Port Authority for review.

\section{Portable Fire Extinguishers}

Portable fire extinguishers were required to be provided for all spaces in accordance with the FDNY Directive, Rules for Portable Fire Appliances (dated September 17, 1980) and Section 27-4009 of the New York City Fire Prevention Code (dated July 1, 1988).

\subsection{FIRE ALARM}

Requirements for fire alarm systems appear in the Electrical Design Guidelines, Specifications and Standard Details for Electrical, Communications and Fire Alarm and in the Mandated Fire Alarm Guidelines for the WTC Base Building Fire Alarm System Design, Construction, Maintenance and Technical Support Services. 
The Electrical Design Guidelines provided limited criteria for HVAC systems and the requirements for smoke detection systems.

The Mandated Fire Alarm Guidelines (issued subsequent to the Electrical Design Guidelines) were intended as a resource to the fire alarm design engineer tasked with interfacing to the WTC Base Building Fire Alarm System. The Fire Alarm System Design Guideline was applicable to the WTC Class E Base Building Fire Alarm Systems installed in WTC 1 and WTC 2 after the 1993 bombing.

The Fire Alarm System Design Guideline describes the backbone system architecture, distribution of terminal strip cabinets, ALD terminal cabinets, riser/one-line diagrams, fire detection and interface devices, visual notification appliances (strobes), audible notification appliances (speakers), wiring and acceptance test procedures.

\subsection{FIREPROOFING}

The only reference in the Architectural and Structural Design Guidelines for fireproofing is an item under the heading Light Weight Ceiling Support System for Floors w/Double Truss. The item states: "Removal of fireproofing shall be kept to a minimum and shall be replaced by the contractor as directed by the Port Authority."

\subsection{EGRESS}

The Architectural and Structural Design Guidelines required an egress analysis to be a part of all submissions in which the proposed work affects the movement of people through the space. The analysis was required to include the following minimum information:

- Construction Classification/Occupancy Classification

- Generally office space and related spaces shall be designed to meet the requirements of Occupancy Group E classification and Construction Class I-B, in accordance with the latest edition of the BCNYC.

- Entrance and Egress

- All exit doors and their sizes to be used to exit any space must be indicated on the drawing, as well as the allowed occupant load per exit width in accordance with the BCNYC.

- Travel Distances

- Travel distances to primary and secondary exits must be indicated following the path of travel through each space.

- Occupant Load

- The office floors have been designed to sustain a live load, including partitions, which shall not be exceeded. In areas where there is a concentration of files, storage, or heavy 
equipment, verification of the structural integrity of the floor system in these areas is required.

\subsection{ELEVATORS AND HOISTWAYS}

The Architectural and Structural Design Guidelines required all core walls to have a $2 \mathrm{~h}$ fire rating as required by the BCNYC. Since the elevators and hoistways were located in the core areas of WTC 1 and WTC 2, the requirement for $2 \mathrm{~h}$ fire ratings would have applied to the elevators and hoistways. 
This page intentionally left blank. 


\section{Chapter 5 \\ Operation And Maintenance Manuals}

The Maintenance Methods section of the Maintenancc Engineering Design Division, Engineering Department of Port Authority of New York and Ncw Jersey (PANYNJ or Port Authority), established Operation and Maintenance Manuals for various systems throughout the World Trade Center (WTC). The instructions and recommendations of the manuals wcre created to aid and guide WTC personnel who operated and maintained the various systcms in the WTC. There are 34 manuals each with a different publication date most of which were finalized in the 1980s. Because not all of the manuals are applicable to the purpose of this report, only those portions of the manuals associated with the fire protection and fire alarm systems will be summarized.

The inspection and maintenance procedures of the various building systems were outlined on Maintenance Procedure Cards (MPCs). The work to be done and the associated intervals are outlined in the following sections.

\subsection{FIRE SUPPRESSION}

Instruction Manuals \#13 (1981), \#18 (1987), and \#23 (1986) establish, among other things, inspection and maintenance procedures for the multiple fire sprinkler, standpipe, and special hazard systems located throughout the WTC. The fire sprinkler inspection and maintenance procedures are outlined on MPC numbers F-2H, M-86, M-137 and E-8. The procedures are as follows:

\section{MPC F-2H}

Work to be Done: Inspect and test sprinkler flow alarm system.

Frequency: 5 times per year. (Drain valves and inspector's test valves only)

Annually. (Main control valves)

Description:

1. A visual inspection should be made to determine that:

a. Sprinklers are not painted, corroded, or physically damaged.

b. High temperature sprinklers are used where excess ceiling temperatures exist. (Be aleit to newly installed heat producing dcvices.)

c. A supply of extra sprinklers is available. (Note special type used in refrigerated spaces.)

d. There is no obstruction to sprinkler water distribution by high-piled material or partitions. (At least $18 \mathrm{in.} \mathrm{of} \mathrm{clearance} \mathrm{is} \mathrm{required;} 36 \mathrm{in.} \mathrm{if} \mathrm{sprinklers} \mathrm{are} \mathrm{the} \mathrm{spray} \mathrm{type} \mathrm{and} \mathrm{stored}$ material consists of large, closely packed piles of cases, bales, or cartons.) 
2. If applicable, operate main sprinkler control valves and ensure reception of tamper switch alarm operation at the Police Security Desk. (Annually.)

3. Return control valves to open position and test all sprinkler flow alarms with actual flow by operating the drain valve or the inspector's test valve.

4. Ensure reception of a flow alarm at the Police Security Desk and local annunciator panel (if applicable) within specified time limit.

5. Ensure reception of main supply flow alarm on the annunciator panel in the control room on Level B4.

6. Check for proper shutdown of all interconnected fans.

7. Return system and interlocked fans to operating conditions.

8. Report unusual conditions to appropriate authority verbally and in writing.

9. Record inspection and testing of system in log.

\section{MPC M-86}

Work to be Done: Check for proper operation of the high and low water alarms on fire reserve tanks.

Frequency: Annually.

Description:

1. Make arrangements to have test witnessed by the Risk Management Division and the insurance carriers.

2. Coordinate test with the Electrical section's cleaning, inspecting, and testing.

3. Inform the WTC police of the test.

4. Install the sprinkler pump test manifold on the 6" sprinkler pump test connection located on the West Street wall of the Customs House. Note: When testing the pump on the 108th floor, open the test line to the sprinkler reserve tank on the 110 th floor.

5. Secure the sprinkler pump on the other tower.

6. Start the pump and take the following readings with a closed discharge at rated capacity and at 150 percent capacity:

a. Flow rate

b. Discharge pressure 
c. Suction pressure

d. Pump speed

7. Record all readings and findings in the maintenance history log.

8. Report all deficiencies verbally to the foreman and in writing on the routine work order.

\section{MPC M-137}

Work to be Done: Check high and low water alarms on fire reserve tanks.

Frequency: 5 times per year.

Description:

1. Fill tank until high water alarm is activated. Tanks should need only a few inches of additional water for alarm activation.

2. Drain tank until low water alarm is activated.

3. Refill tank to normal level.

\section{MPC E-8}

Work to be Done: Clean, inspect and test pump motor and associated controls.

Frequency: Annually.

Description:

1. Coordinate the cleaning, inspecting, and testing of the pump motor with the fire pump capacity test to be performed by the mechanical section.

2. Inform the WTC police of the pump shutdown.

3. De-energize motor and place an "Out of Service" tag on the motor starter.

4. Lockout and ground all feeders and equipment.

5. Clean housing and interior of control pancl.

6. Replace defective contacts, if any, in pairs and return discarded contacts to the shop.

7. Tighten all electrical connections.

8. If possible, blow out or vacuum clean motor starter and rotor windings.

9. Report any evidence of corrosion and dampness to the foreman. 
10. Reenergize motor.

11. Test run and take amprobe readings required by the mechanical test and compare them to the motor nameplate rating. Ratings should not be more than 90 percent of nameplate rating.

12. Check for unusual noise or vibration.

13. Inspect motor controller for overheating and check for defective contacts.

14. Check all aluminum current carrying connections with the infrared heat gun and note all temperatures above $120^{\circ} \mathrm{F}$.

15. Record all readings and findings in the maintenance history log.

16. Replace all defective indicator lamps.

17. Report all deficiencies verbally to the foreman and in writing on the routine work order.

\section{Halon Systems}

The inspection, maintenance and testing of the halon systems were performed by two outside contractors. One was responsible for the fire detection, warning and activation subsystems and the other was responsible for the halon extinguishing subsystem. The annual and semi-annual inspection procedures conformed to the recommended service routines required in National Fire Protection Association 12A and the listed manufacturer's maintenance and service manuals. The procedures were as follows:

\section{Fire Detection, Warning and Activation Subsystems}

The semiannual inspection of the fire detection, warning and activation subsystems include the following:

1. A visual inspection of the 88 ionization detector heads, and the removal of loose dust accumulation by gently tapping the detector head.

2. Activation of one detector in each of the 11 protected areas, resetting the system after each alarm, and checking for all required alarm signals.

3. Repetition of Step \#2 on at least one detector with only battery power applied to the system.

4. A check of the supervisory circuit and associated signals by placing the system in a Trouble condition.

5. The taking of voltage reading, the checking of water levels, and the cleaning of cases of all system batteries.

6. A check of all system components for obvious physical damage.

7. The replacement of all burned out system lamps. 
8. The resetting of the system immediately following completion of the inspection.

The anmual inspection of the fire detection, warning and activation subsystems include the following:

1. The semiannual inspection described above.

2. A check of the sensitivity of each of the 88 fire detectors utilizing the test equipment recommended by the detector manufacturer.

3. The activation of every detector, checking that all proper single and cross-zoning indications and alarms are produced, and all subsequent operations including interlocks with other systems and equipment function properly.

4. The activation of all manual-electric controls while checking for proper operation and response.

5. A check of the operation of the Purge control Panel.

\section{Halon Fire Extinguishing Subsystem}

The semiannual inspection of the halon fire extinguishing subsystem includes the following:

1. The checking of the pressure of all halon 1301 gas cylinders and the recording of this pressure on a permanent log affixed to the cylinder.

2. The removal from the system and the weighing of each halon 1301 cylinder.

3. A check of all system components for obvious corrosion and physical damage.

4. The resetting of the fire extinguishing subsystem immediately following completion of the inspection.

The annual inspection of the halon fire extinguishing subsystem includes the following:

1. The semiannual inspection outlined above.

2. The activation of each halon pressure switch and the checking of alarms.

3. The inspection of all halon 1301 cylinders and cylinder racks for satisfactory condition.

4. A spot inspection of piping and pipe hangers and straps for corrosion and proper support. (At least one full pipe length and related hangers and straps should be inspected in each protected area).

5. A visual inspection of all halon discharge nozzles for proper position, alignment, and clear unobstructed orifices. 


\subsection{FIRE ALARM}

Instruction Manual \#23 establishes, among other things, inspection and maintenance procedures for the fire detection systems located throughout the WTC. The fire alarm inspection and maintenance procedures are outlined on MPC numbers E-10A, E-10B, E-23, E-24, E-25, E-26, E-32, E-36 and E-37. Instruction manual \#12 also provides inspection and maintenance procedures for the Smoke Detection System on the Observation Deck of Tower B. The procedures are as follows:

\section{MPC E-10A}

Work to be Done: Clean, inspect, and test the ventilation smoke alarm system and controls.

Frequency: Annually.

Description:

1. Consult manufacturers' specifications for particular equipment requirements before performing any maintenance work.

2. Prior to testing, notify the Police Security Desk of the test and maintenance.

3. Shut power to control panel.

4. Clean and inspect control panel. Tighten connections. Check for unusual conditions.

5. Reenergize control panel.

6. Check supervisory AC circuit, supervisory DC circuit, and supervision of detector circuit.

7. Disconnect automatic extinguishing devices connected to the system (e.g., halon and carbon dioxide extinguishers).

8. Utilizing a sensitivity test set, test each detector and check for proper response at the control panel and computer center. Log readings.

9. Check that all detector identification labels are proper.

10. Check detector head screen for dust accumulation. If necessary, remove screen and brush clean.

11. The air holes in the air sampling tubes of the air duct detector should be cleaned as required to insure that the unit receives a proper air sample.

12. Test detector in both the static and dynamic conditions. Under dynamic test, check for proper operation of fan shutdown controls. 


\section{Section I}

PANYNJ Guidelines for Inspection, Repair, and Modifications to Fire Protection Systems 
This page intentionally left blank. 


\section{EXECUTIVE SUMMARY}

As part of the analysis of building and firc codes and standards of the National Institute of Standards and Technology World Trade Center (WTC) Investigation, this report supports the effort to document the Port Authority of New York and New Jersey (PANYNJ) guidelines for inspection, repair, and modifications to the fire protection systems in the WTC. Over the life of the buildings, in particular WTC 1, 2, and 7, repairs and modifications were made. These changes, depending on the magnitude of the enhancement, may have affected the ovcrall building performance. The purpose of this report is to document the PANYNJ guidelines for inspection, repair, and modifications to fire protection and egress systems in WTC 1, 2, and 7. These include guidelines governing the inspcction and upgrading of fire alarm and fire suppression systems, the reapplication of fireproofing, and the upgrading of elevators, hoistways, and elevator lobbies.

As part of the document search for this report, manuals, program standards, surveys, and correspondence of many parties were reviewed and analyzed. The following sections provide a summary of the documents that include guidelines and procedures for maintaining and modifying the fire protection and egress systems of the WTC.

\section{Memorandums of Understanding}

The PANYNJ, not being technically subject to the local building code of New York City, created a Memorandum of Understanding (MOU) with the New York City Department of Buildings (NYCDB) in 1993 to establish procedures and avoid construction conflicts. The MOU ensured that any construction project performed by the PANYNJ or any tenant within a PANYNJ building in New York City would conform to the Building Code of the City of New York (BCNYC). The MOU gave the PANYNJ the right to approve building plans. Any variance to the BCNYC, permitted by the PANYNJ, would be sent to the NYCDB for review.

In June of 1995, a supplement to the PANYNJ/NYCDB MOU was added. The MOU supplement permitted PANYNJ tenants to use New York State licensed engineers/architects to self certify construction plans and certify that the installation was in accordance to the certified plans, provided the engineers/architects meets the qualifications established by PANYNJ. The person approving the construction plans could not be the same person certifying that the installation was in accordance with the approved plans until September of 1995, when another supplement was added. The September 1995 supplement permitted a single New York State licensed engineer/architect to certify the construction plans and the installation.

In 1993, a MOU with the PANYNJ and the New York City Fire Department (FDNY) was established. The MOU permitted the FDNY to conduct fire safety inspections at the PANYNJ facilities in New York City. Upon inspection, the findings and recommendations were sent to PANYNJ for review and corrective action if necessary. In 1995, an amendment to the MOU was adopted requiring written notice to the FDNY of any additions or modifications to existing fire safety systems. The amendment also required the design and review of the addition or modification to be performed by a New York State 
licensed engineer or architect. Additionally, the amendment required the design and review of such design to be performed by separate individuals.

\section{Tenant Construction Review Manuals}

The Tenant Construction Review Manuals were created by the Engineering Department, Quality Assurance Division of PANYNJ. The manuals were created to establish technical criteria to be followed by the tenants and their architectural and engineering consultants. Manuals were available from 1971 to 1997. The manuals indicated the applicable codes, standards and PANYNJ criteria that would be used to determine compliance of each modification or addition.

\section{Design Guidelines}

Various design guidelines were created by PANYNJ. Design guidelines were created for all the major construction disciplines. The design guidelines included minimum specifications and standard details for use in the alteration projects throughout the WTC complex. Details pertaining to standpipe systems, fire sprinkler systems, fire alarm systems, fireproofing and egress requirements were included.

\section{Operation and Maintenance Manuals}

The Engineering Department of PANYNJ established Operation and Maintenance Mamuals (34 total) for the various systems throughout the WTC. Each manual contains Maintenance Procedure Cards describing in detail the inspection and maintenance procedures for the work to be done, including the frequency of each test or maintenance. Manuals \#13, \#18, and \#23 describe the details for the fire sprinkler, standpipe and special hazard systems. Manual \#23 and \#12 provides the procedures for the inspection and maintenance of the fire detection systems.

\section{Port Authority Facility Condition Survey Program}

A facility condition survey program was established to continually monitor the condition of the WTC buildings. Engineering firms were contracted by PANYNJ to perform detailed inspections of the building conditions. Various building components, including architectural and structural, were inspected, photos were taken, and reports were generated with recommendations and guidelines for repair or replacement as neccssary. There are at least two reports that detail the inspection and testing of fireproofing materials.

\section{Structural Integrity Testing and Inspection Program}

The Structural Integrity Testing and Inspection Program was established by the PANYNJ Engineering Department and Leslie E. Robertson Associates to monitor the structural integrity of WTC 1 and WTC 2. Although the complete details of this program are not summarized in this report, important procedures for the repair of fire proofing material are discussed. It was recommended to repair fire proofing material with the same brand and type initially used, where practical. Additional procedures were given based on the size of area being repaired and brand of material identified. 


\section{Tenants Manual}

In 1984, the World Trade Center Tenants Mamual was developed to provide WTC tenants information regarding the functions of the Operations Division of WTC. By following building standard requirements, the Operations Division could be contracted by a tenant to make alterations without having to hire an outside contractor or go through the review process with the WTC Planning Department.

\section{Other Documents}

As part of each tenant modification, specifications were created to establish minimum requirements as required by codes. There were literally hundreds of tenant alterations performed in WTC 1, 2, and 7 . Summaries of the alterations on the affected floors of WTC 1 and WTC 2 and all of the alterations in WTC 7 are contained in a separate report. However, a specification to replace fireproofing material on the exposed columns and beams within the elevator shaft of WTC 1 identified additional procedures used at the WTC. This is discussed in Chapter 9 of this report. This specification listed the performance criteria, testing, and inspection requirements for fire proofing material. 
This page intentionally left blank. 


\section{Chapter 1 \\ INTRODUCTION}

Over the course of years, the World Trade Center (WTC) complex and surrounding buildings wcre altered for numerous reasons, including tenant alterations, inspections, building repairs, enhancement, and maintenance. As changes occurred, the need to maintain safety standards arosc. The Port Authority of New York and New Jersey (PANYNJ) adoptcd policies that set forth procedures to maintain and enhance safety standards at PANYNJ facilities. The purpose of this report is to document the PANYNJ guidelines for inspection, repair, and modifications to fire protcction and egress systems in WTC 1, 2, and 7. Thesc include guidelines governed the inspection and upgrading of fire alarm and fire suppression systems, the reapplication of fireproofing, and the upgrading of elevators, hoistways, and elevator lobbies.

The guidelines and policies are found in many PANYNJ documents and involved many parties. Manuals, program standards, surveys, and correspondence have been reviewed and analyzed in an effort to summarize the modification guidelines. Documents containing important information used in the process of performing building modifications are summarized in the following sections. 
This page intentionally left blank. 


\section{Chapter 2 \\ MEMORANDUMS OF UNDERSTANDING}

The facilities of the Port Authority of New York and New Jersey (PANYNJ or Port Authority), an interstate compact under the U.S. Constitution, are not technically subject to the requirements of the local building codes, although PANYNJ intended to voluntarily follow the New York City codes where applicable. In order to minimize conflicts between PANYNJ and the New York City requirements for the World Trade Center (WTC), Memorandums of Understanding (MOUs) were executed. One MOU was executed between PANYNJ and the New York City Department of Buildings (NYCDB) in 1993 (PANYNJ 1993a). Another MOU was executed between PANYNJ and the New York City Fire Department (FDNY) also in 1993 (PANYNJ 1993b).

In November 1993, an agreement between PANYNJ and NYCDB was executed to establish procedures and ensure that any construction project of the PANYNJ or any of its tenants at buildings owned or operated by PANYNJ located in New York City conform to the Building Code of the City of New York (BCNYC).

Under the agreement to ensure conformance with the standards set forth in the Code at the time of design, the parties agreed that the design and review of such systems be performed by New York State licensed architects and engineers. Also, the New York State licensed architect and/or engineer approving the plans for any addition or modification for the Port Authority may not have assisted in the preparation of such plans. The Port Authority agreed to have each tenant obtain a certification from a New York State licensed architect or engineer that such system was constructed in accordance with the approved plans and specifications. For systems effectuated by the Port Authority, the Chief Engineer or his successor in duties was to certify that the system was constructed in accordance with the approved plans and specifications. The Port Authority was to maintain a file for each project, which would contain the most current documents, including certifications, necessary to justify code conformance. NYCDB was permitted, to at any time, request the Port Authority to provide NYCDB with a copy of any fire safety file. Any variance with the codes approved by the Chief Engineer of PANYNJ was to be sent to NYCDB. If NYCDB disagreed with the variance, NYCDB was to advise PANYNJ. Any matters of code conformance not resolved were subject to further review of PANYNJ Board of Commissioners. The MOU also indicates that PANYNJ would continue to conduct or cause to be conducted all building inspections, during both construction and post-construction periods. PANYNJ is to continue to perform structural integrity inspections on a cyclical basis for all of its structures located in New York City.

In June 1995, a supplement was added to the PANYNJ/NYCDB MOU. NYCDB had instituted an optional plan review system since the execution of the original MOU. The supplement requires WTC tenants to utilize New York State licensed architects or engineers meeting qualifications established by PANYNJ to certify and review projects, in lieu of any review by the Port Authority. It also states that the person who reviews and certifies the construction plans for code conformance cannot be the same person that certifies that construction has been performed in accordance with the approved plans. 
In September 1995, a change to the supplement of the PANYNJ/NYCDB MOU was executed in connection with the PANYNJ's Tenant Self-Ccrtification Program at the WTC. The change allows a single New York State licensed architect or engineer to certify both the construction plans and that construction is in conformance with the approved plans with the following exception if the alteration changes the character of the occupancy group under paragraph 27-237 of the BCNYC that would have been applicable had such space been located in a privately owned building.

In December 1993, procedures were set forth to implement the existing policy established in April 1993 between PANYNJ and FDNY. The Port Authority agreed to permit FDNY, acting through its Bureau of Fire Prevention (BFP), to conduct fire safety inspections at any PANYNJ facility in New York City. Upon inspection, BFP was to issue a report of fire safety findings and recommendations for corrective action with respect to any deficiencies to the Port Authority's General Manager of Risk Management operations. The Port Authority would undertake the implementation of such findings and corrective actions and notify BFP of the actions taken. BFP also had the right to conduct follow-up inspections with respect to any recommendations to PANYNJ.

In 1995, an Amendment to the PANYNJ/FDNY MOU was executed with respect to additions and/or modifications to existing fire safety systems. The Port Authority was to notify BFP in writing prior to the introduction of any additions or modifications to existing fire safety systems in a PANYNJ facility in the City of New York. BFP agreed to permit PANYNJ to review additions and/or modifications to existing fire safety systems. To ensure conformance with the standards set forth in local codes and regulations, the design and review of such systems were required to be performed by New York State licensed architects and engineers. Also, the New York State licensed, architect and/or engineer approving the plans for any addition or modification was not to have assisted in the actual preparation of such plans. This provision was later modified (September 1995) to permit the same New York State licensed architect or engineer to prepare and certify that plans met current code requirements.

The Port Authority agreed to require each tenant to obtain a certification from a New York State licensed architect or engineer that modifications were constructed in accordance with the approved plans and specifications. For systems effectuated by PANYNJ, the Port Authority Office of Risk Management would certify that the system was constructed in accordance with the approved plans and specifications. PANYNJ would maintain a file for each new or modified system, which would contain the most current documents, including certifications, necessary to justify code conformance. BFP could at any time request PANYNJ to provide BFP with a copy of any fire safety file. BFP could also audit any new or modified fire safety system to ensure conformance with the standards set forth in local codes and regulations. However, when circumstances or conditions were unusual, the Port Authority could petition the BFP for a variance.

Whenever work was done in the WTC buildings, a project number was assigned by the Port Authority under which all contracts, drawings, and correspondence was filed. These numbers are typically of the format W(yy)-1234 (where yy is the year initiated and 1234 is a four-digit number). This report includes these numbers as references to individual projects, and files retained by the Port Authority are identified by these numbers. 


\section{Chapter 3 \\ Tenant Construction Review Manuals}

The Tenant Construction Review Manual (the Manual) was prepared by the Engineering Department, Quality Assurance Division of the Port Authority of New York and New Jersey (PANYNJ or Port Authority). Manuals were available between 1971 and March 1997. The Manual presents technical criteria to be followed by tenants and their architectural and engineering consultants at all Port Authority facilities, including the World Trade Center (WTC) complex. The following guidelines for inspection, repair, and modifications to fire protection and egress systems are from the March 1997 (latest) edition of the Manual.

\subsection{GENERAL}

Each chapter or section of the Manual refers to compliance with the applicable codes, standards, and Port Authority design criteria listed in the particular section. The codes and regulations referenced for use in New York City include the following:

1. New York City Building Code and its Reference Standards

2. New York City Fire Prevention Code and Directives

3. New York City Local Laws

4. Rules of the Board of Standards and Appeals

5. New York State Labor Law

6. New York State Multiple Dwelling Law (Hotels)

7. New York State Energy Conservation Construction Code

8. Directives and Memoranda of the Department of Buildings

9. Rules of the City of New York, Title 1, Department of Buildings

10. New York City Electrical Code

11. National Electrical Code

Additionally, tenant modifications at all Port Authority facilities were required to comply with the Americans with Disabilities Act and applicable Flood Controls.

In addition to the Reference Standards referenced in the Building Code of the City of New York (BCNYC), the following standards are specifically referenced: 
1. National Fire Protection Association (NFPA) 75, Computer Rooms

2. NFPA 20, Centrifugal Fire Pumps

3. NFPA 30, Flammable and Combustible Liquids Code

4. NFPA 54, National Fuel Gas Code

5. NFPA Standards in areas not covered by codes

In addition to the Port Authority design criteria, Section 14 of the Manual outlines the requirements for acceptance (approval) of materials, assemblies, forms, methods of construction, and the intended use of equipment, as well as the requirements for inspection of materials, assemblies, and construction. The requirements for the approval/acceptance of materials and equipment and the requirements for controlled inspections are abstracted from the BCNYC.

\section{$3.2 \quad$ FIRE SUPPRESSION}

The guidelines for the installation and alteration of sprinkler and fire suppression systems are included in:

- Section $10-$ Mechanical

- Section 11 - Plumbing

- $\quad$ Section 12 - Fire Protection

Section 10 - Mechanical covers fire suppression systems and controls. For the WTC, the Port Authority Design Criteria refers to the published WTC guidelines for heating, ventilating, and air conditioning and Fire Safety systems (see Design Guidelines below).

Section 11 - Plumbing covers fire sprinklers and standpipes. At the WTC, the Port Authority Design Criteria for plumbing and fire protection work was required to conform to the Tenant Plumbing/Fire Protection Design Guidelines (see Design Guidelines below). Details of the representative fire protection items reviewed by the PANYNJ include:

- Fire standpipe systems: floor plans, riser diagrams and available water pressure.

- Sprinkler/fire protection systems: water supplies, mains, risers, valves, siamese connections, etc., principal construction features of the building, electrical or automatic devices, and hydraulic calculations as required by NFPA 13.

- Other fire suppression systems: plans for chemical or gaseous fire suppression piping systems were required to contain: the type of extinguishing agent and number and size of agent containers, size, length and type of all piping used, number and location of all fusible links or detectors and the temperature setting.

Section 12 - Fire Protection covers the design of various fire detection, alarm and suppression systems. Details of representative fire protection items reviewed by the PANYNJ include: 
- Sprinkler and other systems using dry chcmicals, foams, gascous, and other extinguishing agents shall be shown on drawings, signcd and scalcd by the Architcet or Enginecr of record, or if prepared by a specialized consultant, signed and scaled by such licensed consultant. Said consultants must be licensed to practice in the state in which the work will be performed.

- Sprinkler plans shall indicate or list the appropriate information and data specified in NFPA 13 regarding availablc water sources, supply pressure, number and typc of sprinklcrs, fire department connections, hazard classification, alarm dcviccs, and supcrvisory connections. Hydraulic computations shall be submitted when uscd.

\subsection{FIRE ALARM}

Section 12 - Fire Protection covers the design of various fire detection, alarm and suppression systcms. For the WTC complex, the Port Authority Design Criteria includes specific requircments for:

- Wiring: including general, initiating devicc circuits (smokc and heat detectors, system interfaces and manual pull stations), notification appliance circuits, control circuits and power supply.

- System: All components connected to the WTC Base Building Fire Alarm System were required to be fully compatible with the Base System. Undcrwriters Laboratories, Inc./Materials and Equipment Acceptance listings, cross listings and manufacturers' approvals were required. Additional requirements include: field circuits, relay control circuits and conventional inputs (waterflow, tamper, alarm and trouble from tenant panels).

Details of the representative fire protection items reviewed by the PANYNJ include a complete fire alarm riser diagram showing locations of all manual pull stations, visible and audible alerting devices, control panels and wiring where required to be provided.

\section{$3.4 \quad$ FIREPROOFING}

No specific design criteria is specified in Section 5-Architectural, however, the Details of Architectural Review include fire protection of building components and finishes (including documentation verifying that all materials and equipment used are of an approved type).

Section 14 - Materials, Operations and Equipment Approval and Inspection includes the requirements for acceptance (approval) of materials, assemblies, etc. and the requirement for controlled inspections of materials, assemblies and construction.

Spray-on fireproofing, in accordance with BCNYC Sec. 27-345(h), is specifically listed as an item subject to controlled inspection. Such inspection is required to be made and witnessed by or under the direct supervision of a registered architect or professional engineer. 


\section{$3.5 \quad$ EGRESS}

Section 5 - Architectural covers the scope of the architectural review consisting of compliance with the applicable codes, standards and PANYNJ design criteria. Other than the referenced codes and regulations, no specific means of egress design criteria is stated.

The Details of Architectural Review in Section 5 include egress, establishing occupant load and existing capacity, including door and hardware requirements.

In addition, Section 10-Mechanical includes requirements for smoke detectors and fire/smoke dampers at ducts entering "safe areas," exit passageways and lobbies. 


\section{Chapter 4 \\ DESIGN GUIDELINES}

The Port Authority of New York and New Jersey (PANYNJ or Port Authority) preparcd scveral Design Guidelines, Specifications and Standard Details for use in construction and altcrations at the World Trade Center (WTC) complex. The following guidelines were reviewed for critcria pertaining to the maintenance and modifications of fire protection and egress systems:

- Architectural and Structural Design Guidelines, Specifications and Standard Details February 27, 1998.

- Design Guidelines, Specifications and Standard Details Program for heating, ventilating, and air conditioning (HVAC), Fire Protection and Plumbing - Revised May 11, 1998.

- Electrical Design Guidelines, Specifications and Standard Details for Electrical, Communications and Fire Alarm - November 25, 1997.

- Mandated Fire Alarm Guidelines for the WTC Base Building Fire Alarm System Design, Construction, Maintenance and Technical Support Services - March 1999.

The following sections outline the inspection, repair, and modification criteria established for the fire protection and egress systems.

\subsection{GENERAL}

The Design Guidelines were intended to provide design requirements and criteria for tenant alterations at WTC. The design specifications were intended to provide the tenant's consultant engineer with WTC requirements for each of the respective trades. The substance of the specifications was required to be included in the construction documents.

The scope of the architectural and engineering reviews was to ensure compliance with the applicable codes, standards and WTC Design Criteria.

Although the scope of this report does not address compliance with the Americans with Disabilities Act (ADA), several references are made to ADA regarding egress requirements, such as door hardware and access/corridor dimensions and visual warning devises (strobes) connected to the fire alarm system.

\subsection{FIRE SUPPRESSION}

The Design Guidelines, Specifications and Standard Details Program for HVAC, Fire Protection and Plumbing outline the criteria for wet-pipe sprinkler systems, preaction systems, fire standpipe systems, clean agent extinguishing systems, halon fire extinguishing systems and portable fire extinguishers as follows: 


\section{Wet-Pipe Sprinkler Systems}

All tenant spaces were required to be sprinklered. At the time the Design Guidelines were published, most tenant floors in the WTC were provided with wet-pipe sprinkler systems. New tenants normally required a new sprinkler system. For renovations of existing spaces, modifications to the existing system would normally need to comply with any new partition configuration.

Sprinkler work was required to be designed to comply with the requirements of the Building Code of the City of New York (BCNYC), National Fire Protection Association (NFPA) 13 and the PANYNJ design guides. In areas requiring specialized sprinkler systems, additional applicable standards as referenced in NFPA 13 were required to be used for design, including but not limited to the following NFPA 15,16 , 231 , and $231 \mathrm{C}$.

Sprinkler systems were required to be hydraulically designed. A pipe schedule design was only permitted for minor renovations that did not change the number of heads, and where only a few existing sprinkler heads required relocation.

\section{Preaction Systems}

Only a single zone detecting system was required to be used. Actuation of the fire detection system was required to open the preaction valve permitting water to flow into the sprinkler system piping. Sprinkler pipe sizing was required to be hydraulically calculated.

Preaction systems may have been required when wet-pipe sprinkler systems were not provided in computer rooms to protect the areas above the raised floor. As an alternative, a total flooding, clean agent fire extinguishing system was permitted. Areas under raised floors, where wiring was installed in raceways and combustibles are limited, only required smoke detector protection. If the amount of combustibles was extensive, and/or the cabling was not in raceways, these areas were required to be protected by a carbon dioxide system or an approved total flooding, clean agent system.

\section{Fire Standpipe Systems}

In WTC 1 and WTC 2, three fire standpipe risers supplied water to the hose stations on Floors 1 through 110. Risers FS-F1, FS-F2 and FS-F3 were located in Stairway B (Stairway 3), C (Stairway 2), and A (Stairway 1), respectively. Riser FS-F1 supplied water to all hose racks in Stairway B and also to all auxiliary hose cabinets in the corridors and tenant areas.

In WTC 1 and WTC 2, tenant auxiliary standpipe systems were only permitted to be connected to the existing capped outlets provided at fire standpipe riser FS-F1 located in Stairway B.

\section{Clean Agent Fire Extinguishing Systems}

New installations of gas-fired extinguishing systems were permitted in the WTC where the systems were approved by New York City.

Inspection, testing and maintenance of automatic gas systems was required to be performed by competent contractors. Recorded results were required to be submitted to the WTC Fire Safety Coordinator. 
Inspection, testing and maintenance was required to conform to the recommended routincs outlined in NFPA 2001, the BCNYC, the New York City Fire Department (FDNY) Directive reference and the manufacturer's maintenance and scrvice manuals.

A separate duct purge system (minimum of 6 air changes per hour of exhaust ratc) was required to exhaust the discharging gas to the outdoors. The cxhaust duct was required to be arranged so no gas was allowed to infiltrate into other spaces.

Complete contract drawings, specifications and testing procedures were requircd to bc submitted to the Port Authority for review with the Tenant Altcration Application.

\section{Halon Fire Extinguishing Systems}

New halon fire extinguishing systems were not permitted to be installed in the WTC.

When an existing halon system was to be abandoned, the halon storage containers were to be carefully removed so that halon would not be discharged. Containers were required to be returncd for recycling, or recovery of the agent when no longer needed, to comply with NFPA 12A, Sec. 2-1.4.2 (1992 Edition).

If a tenant decided to keep an existing halon fire protection system, the following tasks were required to be performed:

1. Inspection, testing and maintenance of automatic halon systems were required to be performed by competent contractors. Recorded results were required to be submitted to the WTC Fire Safety Coordinator.

2. Inspection, testing and maintenance was required to conform to the recommended routine outlined in NFPA 12A, FDNY Directives (dated October 22, 1990) and the manufacturer's maintenance and service manuals.

3. A complete testing specification was required to be submitted to the Port Authority for review.

\section{Portable Fire Extinguishers}

Portable fire extinguishers were required to be provided for all spaces in accordance with the FDNY Directive, Rules for Portable Fire Appliances (dated September 17, 1980) and Section 27-4009 of the New York City Fire Prevention Code (dated July 1, 1988).

\subsection{FIRE ALARM}

Requirements for fire alarm systems appear in the Electrical Design Guidelines, Specifications and Standard Details for Electrical, Communications and Fire Alarm and in the Mandated Fire Alarm Guidelines for the WTC Base Building Fire Alarm System Design, Construction, Maintenance and Technical Support Services. 
The Electrical Design Guidelines provided limited criteria for HVAC systems and the requirements for smoke detection systems.

The Mandated Fire Alarm Guidelines (issued subsequent to the Electrical Design Guidelines) were intended as a resource to the fire alarm design engineer tasked with interfacing to the WTC Base Building Fire Alarm System. The Fire Alarm System Design Guideline was applicable to the WTC Class E Base Building Fire Alarm Systems installed in WTC 1 and WTC 2 after the 1993 bombing.

The Fire Alarm System Design Guideline describes the backbone system architecture, distribution of terminal strip cabinets, ALD terminal cabinets, riser/one-line diagrams, fire detection and interface devices, visual notification appliances (strobes), audible notification appliances (speakers), wiring and acceptance test procedures.

\subsection{FIREPROOFING}

The only reference in the Architectural and Structural Design Guidelines for fireproofing is an item under the heading Light Weight Ceiling Support System for Floors w/Double Truss. The item states: "Removal of fireproofing shall be kept to a minimum and shall be replaced by the contractor as directed by the Port Authority."

\subsection{EGRESS}

The Architectural and Structural Design Guidelines required an egress analysis to be a part of all submissions in which the proposed work affects the movement of people through the space. The analysis was required to include the following minimum information:

- Construction Classification/Occupancy Classification

- Generally office space and related spaces shall be designed to meet the requirements of Occupancy Group E classification and Construction Class I-B, in accordance with the latest edition of the BCNYC.

- Entrance and Egress

- All exit doors and their sizes to be used to exit any space must be indicated on the drawing, as well as the allowed occupant load per exit width in accordance with the $\mathrm{BCNYC}$.

- Travel Distances

- Travel distances to primary and secondary exits must be indicated following the path of travel through each space.

- Occupant Load

- The office floors have been designed to sustain a live load, including partitions, which shall not be exceeded. In areas where there is a concentration of files, storage, or heavy 
equipment, verification of the structural integrity of the floor system in these areas is required.

\subsection{ELEVATORS AND HOISTWAYS}

The Architectural and Structural Design Guidelines required all core walls to have a $2 \mathrm{~h}$ fire rating as required by the BCNYC. Since the elevators and hoistways were located in the core areas of WTC 1 and WTC 2, the requirement for $2 \mathrm{~h}$ fire ratings would have applied to the elevators and hoistways. 
This page intentionally left blank. 


\section{Chapter 5 \\ Operation ANd Maintenance Manuals}

The Maintenance Methods section of the Maintenancc Enginecring Design Division, Engineering Department of Port Authority of New York and New Jersey (PANYNJ or Port Authority), established Operation and Maintenance Manuals for various systems throughout the World Trade Center (WTC). The instructions and recommendations of the manuals were created to aid and guide WTC personnel who operated and maintained the various systems in the WTC. There are 34 manuals each with a differcnt publication date most of which were finalized in the 1980s. Because not all of the manuals are applicable to the purpose of this report, only those portions of the manuals associated with the fire protection and fire alarm systems will be summarized.

The inspection and maintenance procedures of the various building systems were outlined on Maintenance Procedure Cards (MPCs). The work to be done and the associated intervals are outlined in the following sections.

\subsection{FIRE SUPPRESSION}

Instruction Manuals \#13 (1981), \#1 8 (1987), and \#23 (1986) establish, among other things, inspection and maintenance procedures for the multiple fire sprinkler, standpipe, and special hazard systems located throughout the WTC. The fire sprinkler inspection and maintenance procedures are outlined on MPC numbers F-2H, M-86, M-137 and E-8. The procedures are as follows:

\section{MPC F-2H}

Work to be Done: Inspect and test sprinkler flow alarm system.

Frequency: 5 times per year. (Drain valves and inspector's test valves only)

Annually. (Main control valves)

Description:

1. A visual inspection should be made to determine that:

a. Sprinklers are not painted, corroded, or physically damaged.

b. High temperature sprinklers are used where excess ceiling temperatures exist. (Be alert to newly installed heat producing devices.)

c. A supply of extra sprinklers is available. (Note special type used in refrigerated spaces.)

d. There is no obstruction to sprinkler water distribution by high-piled material or partitions. (At least 18 in. of clearance is required; 36 in. if sprinklers are the spray type and stored material consists of large, closely packed piles of cases, bales, or cartons.) 
2. If applicable, operate main sprinkler control valves and ensure reception of tamper switch alarm operation at the Police Security Desk. (Annually.)

3. Return control valves to open position and test all sprinkler flow alarms with actual flow by operating the drain valve or the inspector's test valve.

4. Ensure reception of a flow alarm at the Police Security Desk and local annunciator panel (if applicable) within specified time limit.

5. Ensure reception of main supply flow alarm on the annunciator panel in the control room on Level B4.

6. Check for proper shutdown of all interconnected fans.

7. Return system and interlocked fans to operating conditions.

8. Report unusual conditions to appropriate authority verbally and in writing.

9. Record inspection and testing of system in log.

\section{MPC M-86}

Work to be Done: Check for proper operation of the high and low water alarms on fire reserve tanks.

Frequency: Annually.

Description:

1. Make arrangements to have test witnessed by the Risk Management Division and the insurance carriers.

2. Coordinate test with the Electrical section's cleaning, inspecting, and testing.

3. Inform the WTC police of the test.

4. Install the sprinkler pump test manifold on the 6" sprinkler pump test connection located on the West Street wall of the Customs House. Note: When testing the pump on the 108th floor, open the test line to the sprinkler reserve tank on the 110 th floor.

5. Secure the sprinkler pump on the other tower.

6. Start the pump and take the following readings with a closed discharge at rated capacity and at 150 percent capacity:
a. Flow rate
b. Discharge pressure 
c. Suction pressure

d. Pump specd

7. Record all readings and findings in the maintenance history log.

8. Report all deficiencies verbally to the foreman and in writing on the routine work order.

\section{MPC M-137}

Work to be Done: Check high and low water alarms on fire reserve tanks.

Frequency: 5 times per year.

Description:

1. Fill tank until high water alarm is activated. Tanks should need only a few inches of additional water for alarm activation.

2. Drain tank until low water alarm is activated.

3. Refill tank to normal level.

\section{MPC E-8}

Work to be Done: Clean, inspect and test pump motor and associated controls.

Frequency: Annually.

Description:

1. Coordinate the cleaning, inspecting, and testing of the pump motor with the fire pump capacity test to be performed by the mechanical section.

2. Inform the WTC police of the pump shutdown.

3. De-energize motor and place an "Out of Service" tag on the motor starter.

4. Lockout and ground all feeders and equipment.

5. Clean housing and interior of control panel.

6. Replace defective contacts, if any, in pairs and return discarded contacts to the shop.

7. Tighten all electrical connections.

8. If possible, blow out or vacuum clean motor starter and rotor windings.

9. Report any evidence of corrosion and dampness to the foreman. 
10. Reenergize motor.

11. Test run and take amprobe readings required by the mechanical test and compare them to the motor nameplate rating. Ratings should not be more than 90 percent of nameplate rating.

12. Check for unusual noise or vibration.

13. Inspect motor controller for overheating and check for defective contacts.

14. Check all aluminum current carrying connections with the infrared heat gun and note all temperatures above $120^{\circ} \mathrm{F}$.

15. Record all readings and findings in the maintenance history log.

16. Replace all defective indicator lamps.

17. Report all deficiencies verbally to the foreman and in writing on the routine work order.

\section{Halon Systems}

The inspection, maintenance and testing of the halon systems were performed by two outside contractors. One was responsible for the fire detection, warning and activation subsystems and the other was responsible for the halon extinguishing subsystem. The annual and semi-annual inspection procedures conformed to the recommended service routines required in National Fire Protection Association 12A and the listed manufacturer's maintenance and service manuals. The procedures were as follows:

\section{Fire Detection, Warning and Activation Subsystems}

The semiannual inspection of the fire detection, warning and activation subsystems include the following:

1. A visual inspection of the 88 ionization detector heads, and the removal of loose dust accumulation by gently tapping the detector head.

2. Activation of one detector in each of the 11 protected areas, resetting the system after each alarm, and checking for all required alarm signals.

3. Repetition of Step \#2 on at least one detector with only battery power applied to the system.

4. A check of the supervisory circuit and associated signals by placing the system in a Trouble condition.

5. The taking of voltage reading, the checking of water levels, and the cleaning of cases of all system batteries.

6. A check of all system components for obvious physical damage.

7. The replacement of all burned out system lamps. 
8. The resetting of the system immediatcly following complction of the inspcction.

The annual inspection of the fire detection, warning and activation subsystems include the following:

1. The semiannual inspection described above.

2. A check of the sensitivity of each of the 88 fire detcctors utilizing the test cquipment recommended by the detector manufacturer.

3. The activation of every detcctor, checking that all proper singlc and cross-zoning indications and alarms are produced, and all subsequent operations including interlocks with other systems and equipment function properly.

4. The activation of all manual-elcctric controls while checking for proper opcration and response.

5. A check of the operation of the Purge control Panel.

\section{Halon Fire Extinguishing Subsystem}

The semiannual inspection of the halon firc extinguishing subsystem includes the following:

1. The checking of the pressure of all halon 1301 gas cylinders and the recording of this pressure on a permanent log affixed to the cylinder.

2. The removal from the system and the weighing of each halon 1301 cylinder.

3. A check of all system components for obvious corrosion and physical damage.

4. The resetting of the fire extinguishing subsystem immediately following completion of the inspection.

The annual inspection of the halon fire extinguishing subsystem includes the following:

1. The semiannual inspection outlined above.

2. The activation of each halon pressure switch and the checking of alarms.

3. The inspection of all halon 1301 cylinders and cylinder racks for satisfactory condition.

4. A spot inspection of piping and pipe hangers and straps for corrosion and proper support. (At least one full pipe length and related hangers and straps should be inspected in each protected area).

5. A visual inspection of all halon discharge nozzles for proper position, alignment, and clear unobstructed orifices. 


\subsection{FIRE ALARM}

Instruction Manual \#23 establishes, among other things, inspection and maintenance procedurcs for the fire detection systems located throughout the WTC. The fire alarm inspection and maintenance procedures are outlined on MPC numbers E-10A, E-10B, E-23, E-24, E-25, E-26, E-32, E-36 and E-37. Instruction manual \#12 also provides inspection and maintenance procedures for the Smoke Detection System on the Observation Deck of Tower B. The procedures are as follows:

\section{MPC E-10A}

Work to be Done: Clean, inspect, and test the ventilation smoke alarm system and controls.

Frequency: Annually.

Description:

1. Consult manufacturers' specifications for particular equipment requirements before performing any maintenance work.

2. Prior to testing, notify the Police Security Desk of the test and maintenance.

3. Shut power to control panel.

4. Clean and inspect control panel. Tighten connections. Check for unusual conditions.

5. Reenergize control panel.

6. Check supervisory AC circuit, supervisory DC circuit, and supervision of detector circuit.

7. Disconnect automatic extinguishing devices connected to the system (e.g., halon and carbon dioxide extinguishers).

8. Utilizing a sensitivity test set, test each detector and check for proper response at the control panel and computer center. Log readings.

9. Check that all detector identification labels are proper.

10. Check detector head screen for dust accumulation. If necessary, remove screen and brush clean.

11. The air holes in the air sampling tubes of the air duct detector should be cleaned as required to insure that the unit receives a proper air sample.

12. Test detector in both the static and dynamic conditions. Under dynamic test, check for proper operation of fan shutdown controls. 
13. After completing the alarm tests, reconnect all automatic extinguishing equipment and notify proper authorities.

14. Report any deficiencies to the foreman verbally, and in writing on the routine work order.

\section{MPC E-10B}

Work to be Done: Clean, inspect and test interior return air and elevator lobby smoke alarm systems.

Frequency: Annually.

Description:

1. Notify the Police Security Desk of the test and maintenance.

2. Locate the smoke detector head and activate it using sensitivity tester. Record reading in $\log$ book and check for proper alarm indication at the computer terminal.

3. Remove detector head and check for proper indication at computer terminal.

4. Dust and wash detector head.

5. Replace detector head.

6. Using sensitivity tester, reactivate detector.

7. Reset the controls on panel box and make final check with computer terminal.

8. Report any deficiencies to foreman verbally and in writing on the routine work order.

\section{MPC E-23}

Work to be Done: Service public address system and fire station and intercom console (Executone).

Frequency: Annually.

Description:

1. Prior to testing, notify Police Security Desk and the New York City Fire Department (FDNY).

2. Remove module and replace with spare.

3. Clean contacts with chemicals and burnishing tools.

4. Adjust contact leaf pressure as required.

5. In odd-numbered years only, group relamp indicator lamps. 
6. Replace spare module with service module. Restore to service and test.

7. Report any deficiencies to foreman verbally and in writing on the routine work order.

\section{MPC E-24}

Work to be Done: Service public address system amplifiers (Executone).

Frequency: Monthly.

Description:

1. Remove and clean the air intake filters.

2. Wipe and vacuum clean front blower enclosure.

3. Add 2 drops of non-detergent oil in each of the 2 oil cups per blower.

4. Remove panels in rear of enclosure. Disconnect blower unit. Wipe clean and vacuum rear of blower unit. Pay particular attention to the area of the air flow switch.

5. Wipe clean and vacuum amplifiers and housing.

6. Spot relamp defective indicator lamps on face of enclosure. Once each year, on the first pay period, group relamp.

7. Report any deficiencies to foreman verbally and in writing on the routine work order.

\section{MPC E-25}

Work to be Done: Test public address system amplifiers (Executone).

Frequency: Quarterly.

Description:

1. Test amplifiers with oscilloscope for proper wave shape and output level.

2. Make proper adjustments.

3. Report any deficiencies to foreman verbally and in writing on the routine work order.

\section{MPC E-26}

Work to be Done: Clean, inspect, and test the fire alarm signal boxes.

Frequency: Monthly. 


\section{Description:}

1. Prior to testing, notify the Police Security Office.

2. Deactivate appropriate zone pull box.

3. Clean and lubricate as necessary.

4. Perform operational test. Trip electrically and check for proper operation and indication on fire station system console.

\section{MPC E-32}

Work to be Done: Test fire call boxes.

Frequency: Annually.

Description:

1. Prior to testing, notify the Police Security Office.

2. One man remains at the console while the other tests the local boxes.

3. The roving man should take extra break glass rods with him.

4. Turn the time to maximum on the zone you are working on, and pull the $110 \mathrm{~V} \mathrm{AC}$ clock plug in back of the module. This will keep the rest of the system in auto mode while disabling the one module to be worked on. Note: If an alarm comes in from another box in the zone being tested, notify police to send an alarm to the FDNY.

5. At the fire call box, pay particular attention to the door latch for proper functioning. Lubricate if necessary.

6. Ensure smooth door swing.

7. Remove the break glass and check for the fire call at the console.

8. Check both channels A and B for clear voice communication from station to console.

9. Check for smooth plunger action on the microswitch and lubricate if needed.

10. Log location, date, and results of each test in equipment log.

11. Notify the Police Security Office when the test is completed. Note: Be sure to reinstall the clock plug and reset the timer before leaving.

12. Notify the system foreman of any problems. 


\section{MPC E-36}

Work to be Done: Service facility recording unit.

Frequency: Semiannually.

Description:

1. Notify the Police Security Desk that you are removing recording unit from console.

2. Disconnect all connections to recorder.

3. Remove recorder from console.

4. Maintenance on unit:
a. Clean out dust and dirt.
b. Lubricate moving parts.
c. Make adjustments to linkages if needed.
d. Clean and demagnetize recording heads.
e. Check operation of motors and solenoids.
f. Check condition of drive belts, replace if necessary.

5. Replace recorder in console.

6. Restore all wiring and test for proper operation.

\section{MPC E-37}

Work to be Done: Perform operational check on duct speaker amplifiers.

Frequency: Annually.

Description:

1. Disconnect $70 \mathrm{~V}$ input signal from building base amplifiers (TB-2-2A and 3).

2. Remove amplifier power plug from $110 \mathrm{~V}$ outlet.

3. Connect $70 \mathrm{~V}$ input from test unit to TB-2-2A and 3.

4. Disconnect plug assembly for duct speakers from P-3013 amplifier (TB-1).

5. Install test load plug to amplifier (TB-1). (20 V transformers (4), $100 \mathrm{OHM}$ resistor.)

6. Hook up jumper leads to existing $24 \mathrm{~V}$ line (TB-1). Positive to \#7, negative to \#7A. 
7. Replace $110 \mathrm{~V}$ plug in outlct.

8. Using multimeter, adjust signal generator for $1 \mathrm{~V}, 1000$ cycles into $200 \mathrm{~W}$ test amplifier. This will provide $70 \mathrm{~V}$ input for P-3013 amplifier.

9. Turn on test amp.

10. Leave all potentiometer settings in initial position. Make test to detcrmine standing output voltages for amplifiers and spcaker input. Record this data.

11. Attach mulitmeter to \#1 amplifier output.

a. Adjust \#1 sensitivity control to $1.5 \mathrm{~V}$.

b. Adjust \#1 volume control until approximately $20 \mathrm{~V}$ are attained.

c. Follow above procedurc for remaining amplifier output adjustments.

d. Recheck all outputs, 1 through 4 . Readjust where necessary to achieve $20 \mathrm{~V}$.

c. Attach test speaker for audio output from each speaker transformer.

12. Remove test equipment, restore to operation.

13. Check communications console for proper supervision.

\section{Smoke Detection System for Observation Deck}

The smoke detection system for the observation deck of WTC 2 is to be annually inspected, as a whole, in the following manner:

Fire Damper and Fire Door Bypass

Before carrying out any servicing and testing, perform the following:

1. Bypass the fire dampers by placing the Fire Damper Bypass Switch in the ON position.

2. Bypass the rollup fire doors by placing the Rollup Fire Door Bypass Switch in the ON position.

\section{Control Panels}

Service the control panels annually as described below:

1. Disconnect power to the control panels.

2. Clean and inspect the control panels. Tighten connections. Check for unusual conditions.

3. Reenergize the control panels. 


\section{Supervisory Circuits}

1. Check the supervisory circuit of the AC power supply to the control panels as follows:
a. Disconnect power supply to the panels.
b. Check for proper trouble alarm indication at the Computer-Multiplex Console in the Security Room.

2. Check the supervisory circuit of the DC power supply to the smoke detectors and alarm and trouble bells by disconnecting the power supply to the smoke detectors and smoke alarm and trouble bells.

3. Check for trouble alarm indication at the Computer-Multiplex Console in the Security Room.

\section{Manual Fire Alarn Stations}

Check the electrical and mechanical functioning of each station as follows:

1. Operate the station.

Note: If the station cannot be operated, there is a mechanical problem and it should be corrected.

2. Check for proper alarm indication at the Smoke Detection Control Panel on floor 107. Note: If the station is mechanically sound, the electrical circuit is healthy, and there is no proper alarm indication at the Smoke Detection Control Panel on floor 107, there is a problem with the electrical contact in the manual station and it should be corrected.

3. Check for proper smoke alarm indication at the Computer-Multiplex Console in the Security Room.

\section{Ceiling Suloke Detectors}

For each Ceiling Smoke Detector, perform the following tests annually and record results.

1. Locate the smoke detector and remove the detector head. Check for proper alarm indication at the Computer-Multiplex Console after the head is removed. Replace the detector head.

2. Activate the detector using a sensitivity tester ${ }^{1}$ and record the reading in the log book. Check for proper alarm indication at the Computer-Multiplex Console in the Security Room.

3. Remove the detector head and clean it if necessary. Check for proper alarm indication at the Computer-Multiplex Console. Replace the detector head.

1 The sensitivity tester referenced is Model NKT-24, Products of Combustion Detector Tester. The instruction manual is provided in Appendix D of Manual \#12 
4. Activate the detcctor using a scnsitivity tester and record the second reading in the log book.

5. Check for the proper alarm indication at the Computer-Multiplcx Consolc in the Sccurity Room.

\section{Duct Snoke Detectors}

For each duct smoke detector, perform the following tests annually:

1. Clean the air sampling tubes of the detector, to insure that the unit reccives a proper air sample.

2. Activate the detector using a sensitivity tester when the fan is not running (Static Condition) and record the reading in the log book. Check for proper alarm indication at the ComputerMultiplex Console.

3. Activate the detector using a sensitivity tester when the fan is running (Dynamic Condition) and record the reading in the log book. Measure the air velocity across the air sampling tubes and record it in the log book. Check for proper operation of the fan shutdown controls when the fan is running. Check for proper alarm indication at the Computer-Multiplex Console.

After completing the servicing and testing, perform the following:

1. Place the Fire Damper Bypass Switch in the OFF position. Now the fire dampers are in the Smoke Detection System.

2. Place the Rollup Fire Door Bypass Switch in the OFF position. Now the fire doors are in the Smoke Detection System. 
This page intentionally left blank. 


\section{Chapter 6 \\ PORT AUTHORITY FACILITY CONDITION SURVEY PROGRAM}

Various reports from the 1990s for the Port Authority Facility Condition Survey Program have bcen located. The precise guidelines for these programs are unknown; however, extracting from the introductions and executive summaries of the available reports reveals some of the procedures for inspecting building features. The program focuses more toward architcctural and structural aspects, although fire protection features are mentioned.

\subsection{GENERAL}

The Port Authority of New York and Ncw Jersey contracted cngineering firms to perform detailed inspections of building conditions. Inspection procedures varied by task. Visual inspections, material sampling, reviewing maintenance records, and walk-through inspections were performed. Photographs were taken and reports were generated with recommendations and, at times, guidelines for repair/replacement.

\subsection{FIREPROOFING}

The World Trade Center (WTC) Tower "B" report (PANYNJ 1990) includes inspection procedures relating to the fireproofing removal. Inspections were performed by removing the fireproofing from the steel floor framing and examining it for delamination and underlying corrosion. The fireproofing was replaced at the conclusion of the inspection by the WTC Department's structural contractor. Roughly 4 percent of the floor framing trusses and 3 percent of the exterior column spandrel plate splices were inspected on designated office area floors determined before the inspection ( 30 floors total). All four two-story Mechanical Equipment Rooms and selected core columns and elevator shafts were also inspected. The fireproofing was replaced after the inspections. No guidelines for repair were given.

The WTC Tower A report (PANYNJ 1991) followed very similar procedures as Tower B. 
This page intentionally left blank. 


\section{Chapter 7 \\ STRUCTURAL INTEGRITY TESTING AND INSPECTION PROGRAM}

In March 1986, the Infrastructure Engineering Design Division, Engineering Department of the Port Authority of New York and Ncw Jcrsey (PANYNJ or Port Authority) produced Standards for Structural Integrity Inspection of the World Trade Center Towers A and B. These standards, created by Leslic E. Roberson Associates (LERA), were designed to assist PANYNJ in the cvaluation of the on-going structural integrity of World Trade Center (WTC) 1 and WTC 2. The bulk of this program will be addressed in other structural reports of Project 1. However, there is some information that is valuable to the purpose of this section.

As LERA performed Structural Integrity Inspections, reports were generated with recommendations and procedures for enhancing and repairing damaged materials. Included in some reports were procedures for repairing fireproofing. The following section summarizes the fireproofing repair procedures.

\subsection{FIREPROOFING}

Appendix D of Structural Integrity Inspection reports PII33903 and PII73902 established procedures for repairing spray- and trowel-applied fireproofing as follows:

Where practical, identify brand and type of fireproofing initially used (largely CAFCO BLAZE-SHIELD by Isolatek and Grace Monokote in WTC 1 and WTC 2).

As recommended by Underwriters Laboratories, Inc. (UL), repair "in kind."

- Where Isolatek fireproofing products are identified:

- If area is less than $3 \mathrm{ft}^{2}$, prepare surfaces and trowel on CAFCO FIBER-PATCH (by Isolatek) or equivalent per manufacturer's specification.

- For areas greater than $3 \mathrm{ft}^{2}$, one of the following procedures may be used:

a. Prepare surfaces and spray on new BLAZE-SHIELD (by Isolatek) or equivalent per manufacturer's specifications; or

b. Patch with CAFCO FIBER-PATCH (Type P) according to the following: "When the area to be patched is within 1 in. of the flange tip of the steel section, additional material would have to be removed prior to the application of the patching material to insure a proper key. The material to be removed would incorporate the material on the inner face of the flange up to the interface of the material on the web, the flange tips, and at least $1 / 2$ the width of the outer flange face."1

I UL letter dated January 20, 1997. 
- Where Grace fireproofing products are identified:

- If area is less than $1 \mathrm{ft}^{2}$, prepare surfaces and trowel patch fireproofing with Monokote Z-106 or Monokote Z-146 (by Grace) or equivalent per manufacturer's specifications.

- For areas greater than $1 \mathrm{ft}^{2}$, one of the following procedures may be used:

a. Prepare surfaces and spray applied fireproofing with Monokote Z-106 or Monokote Z-146 (by Grace) or equivalent per manufacturer's specifications; or

b. Prepare surfaces, "the Type Z-106 spray applied fire resistive material shall be mixed and sprayed to the appropriate density into a suitable container, then troweled at the required thickness to beams and columns, which have been wrapped following the contour with minimum $1.7 \mathrm{lb} / \mathrm{yd}^{2}$ expanded metal lath. It should be understood that the thickness shall be measured to the face of the lath."2 Key new material into the material surrounding the repair in accordance with manufacturer's recommendations. The integrity of the surrounding material is not to be impaired.

The thickness of repair material shall provide the same fire rating as material initially used.

2 UL letter dated July 24, 1997. 


\section{Chapter 8 \\ TENANTS MANUAL}

The World Trade Center Tenants Mamial was developed in 1984 to provide useful information to World Trade Center (WTC) tenants including, among other things, functions of the Opcrations Division, tcnant alteration procedures, fire safcty information, and rules and rcgulations.

\subsection{GENERAL}

The Operations Division was capable of providing an array of services to the tenants of WTC through the Structural, Tenant Services, Operations, Mechanical, and Electrical sections. Tenants desiring to make alterations could hire the Opcrations Division to perform alterations without having to receive approval from the WTC Planning Division or hire an outside contractor and go through the review process of the WTC Planning Division.

A Design Guide within the WTC Tenant Manual contains basic information for the tenant's architect/engineer that would be designing the tenant space. Within the Design Guide, the Port Authority of New York and New Jersey (Port Authority) committed to provide the tenant's architect/engineer with the necessary WTC drawings and building standard information in the possession of the Port Authority. If the alteration involved other than building standard requirements, the tenant was directed to work with one or more of the WTC consultant engineering firms listed in Table 8-1 below. If the required information could not be provided from the consultants, additional information would be supplied from the WTC Planning Representative. Also, if the need arose to alter fire protection features, the fire protection drawings had to be reviewed and approved by the Port Authority and Employers Group of Insurance Companies.

Table 8-1. WTC consultants, as of 1984.

\begin{tabular}{|l|l|}
\hline Mechanical & Jaros, Baum \& Bolles \\
\hline Electrical and Structural & Joseph R. Loring \& Associates \\
\hline Structural & $\begin{array}{l}\text { Skilling, Helle, Christiansen, \& } \\
\text { Robertson }\end{array}$ \\
\hline
\end{tabular}


This page intentionally left blank. 


\section{Chapter 9 \\ OTHER DOCUMENTS}

There are many other documents that contain procedures for modifying fire protection systems. As part of each tenant alteration, specifications were created to establish minimum requirements as required by codes. There were literally hundreds of tenant alterations performed in World Trade Center (WTC) 1, 2 , and 7. Summaries of the alterations on the affected floors of WTC 1 and WTC 2 and all of the alterations in WTC 7 are summarized in a separate section and will not be discussed here. However, an important specification regarding the installation of the fireproofing material is summarized below. These specifications were not directly established as part of the Port Authority of New York and New Jersey (PANYNJ) guidelines, but were used in the upgrading/enhancement of the WTC buildings.

\section{$9.1 \quad$ FIREPROOFING}

As part of an effort to replace fireproofing for column and beam surfaces exposed within the elevator shafts of WTC 1, specifications for this work were created under Division 7 - Fireproofing. The specification is separated into two sections: 7A - Spray-on Replacement Fireproofing, and 7B - Testing and Inspection of Spray-on Fireproofing (PANYNJ 1993c, 1993d). Highlights of the specification include:

\section{Submittals}

The manufacturer's instructions for proper application were required to be submitted. Independent laboratory test results with the indicated performance criteria were also required to be submitted.

\section{Performance Criteria}

The fireproofing thickness was intended to provide for a minimum fire resistance rating of $2 \mathrm{~h}$ for beams (restrained) and $3 \mathrm{~h}$ for columns. The specified product was W.R. Grace and Co. Type 106. Other products could be used if approved by the Engineer.

- Bond strength per ASTM International (ASTM) E736 - Standard Test Method for Cohesion/Adhesion of Sprayed Fire-Resistive Materials Applied to Structural members.

- Compressive strength per ASTM E761 - Standard Test Method for Compressive Strength of Sprayed Fire-Resistive Materials Applied to Structural Members.

- Air erosion per ASTM E859 - Standard Test Method for Air Erosion of Sprayed FireResistive Materials Applied to Structural Members.

- Corrosion resistance per ASTM E937 - Standard Test Method for Corrosion of Sprayed FireResistive Materials Applied to Structural Members 
- Minimum density per ASTM E605 - Standard Test Methods for Thickness and Density of Sprayed Fire-Resistive Materials Applied to Structural Members.

\section{Testing and Inspection}

All of the tests and inspections were performed by the PANYNJ Materials Division, but the responsibility of the approval was left with the Engineer. The tests and inspections were outlined as follows:

1. Inspect conditions of substrate daily, before application, for proper preparation of steel. Steel shall be free of dirt, grease, release agents, loose scale, extensive rust and loose paint (primer) which will prevent adhesion. Report areas not in compliance immediately for remedial action.

2. Test replacement fireproofing for density and thickness in accordance with ASTM E736.

3. Inspect and note whether or not corrective measures, including patching, have been properly carried out in all areas in nced of re-spraying and patching, including areas where sprayed-on fire protection has been deliberately removed for testing, or has been damaged in any way.

4. Inspect replacement fireproofing for cracks. Replacement material shall not show any visual sign of cracking upon drying and curing.

5. All testing shall be based upon random samples and shall be the responsibility of the PANYNJ Materials Division. 


\section{Chapter 10 \\ REFERENCES}

Frank, Walter M. 1995. Transmittal of Letter Agreement - NYC Department of Buildings. Port Authority of New York and New Jcrsey. October 16.

Goldstein, William H. 1995. Letter agreement for a change to the Supplement to the basic Memorandum of Understanding between the NYC Department of Buildings and the Port Authority of New York and New Jersey. New York City Department of Buildings. September 15.

LERA. Date unknown. Appendix D, Fire Protection Repair Procedures. (Part of Structural Integrity Inspection Report \#PII33903). Date unknown.

LERA. 1990. Structural Integrity Testing and Inspection Progran for The World Trade Center. January 12.

LERA. 1999. Appendix D, Fire Protection Repair Procedures. (Part of Structural Integrity Inspection Report \#PII73902). May.

PANYNJ. 1981. World Trade Center Instruction Manual No. 12, Operation and Maintenance of Snoke Detection System Observation Deck, Tower B. Engineering Department. August.

PANYNJ. 1981. World Trade Center Instruction Manual No. 13, Operation and Maintenance of Halon Fire Protection System Computer Center, WTC. Engineering Department. December.

PANYNJ. 1986. Standards for Structural Integrity Inspection of the World Trade Center Towers A and $B$. Engineering Department. March.

PANYNJ. 1986. World Trade Center Instruction Manual No. 23, Operation and Maintenance of Fire Protection System. Engineering Department. February.

PANYNJ. 1987. Memorandum: Elevator Handicapped Modifications. September 14.

PANYNJ. 1987. World Trade Center Instruction Manual No. 18, Operation and Maintenance Fire Sprinkler Systems. Engineering Department. April.

PANYNJ. 1990. Port Authority Facility Condition Survey Program: World Trade Center Tower B. Engineering Department. April.

PANYNJ. 1991. Memorandum: American with Disability Act of 1990 - Tenant Construction. August 27.

PANYNJ. 1991. Port Authority Facility Condition Survey Program: World Trade Center Tower A Structure Elements. Engineering Department. October. 
PANYNJ. 1993a. Memorandum of Understanding Between the New York City Department of Buildings and the Port Authority of New York and New Jersey. November.

PANYNJ. 1993b. Memorandum of Understanding Between the Fire Department of the City of New York and the Port Authority of New York and New Jersey. December 30.

PANYNJ. 1993c. Division 7 - Fireproofing, Section 7A, Spray-on Replacement Fireproofing. February 10.

PANYNJ. 1993d. Division 7 -Fireproofing, Section 7B, Testing and Inspection of Spray-on Fireproofing. February 10.

PANYNJ. 1995. First Amendment to Memorandum of Understanding Between the Fire Department of the City of New York and the Port Authority of New York and New Jersey.

PANYNJ. 1995. Supplement to Memorandum of Understanding Between the New York City Department of Buildings and the Port Authority of New York and New Jersey. 1995.

PANYNJ. 1996. World Trade Center Retail Tenant Design Criteria. July.

PANYNJ. 1997. Port Authority Facility Condition Survey Program: 7 World Trade Center. Engineering Department. April.

PANYNJ. 1997. Tenant Construction Review Mamual. Engineering Department. March.

PANYNJ. 1997. World Trade Center Electrical Design Guidelines, Specifications and Standard Details. November 25.

PANYNJ. 1998. World Trade Center Architectural and Structural Design Guidelines, Specifications and Standard Details. February 27.

PANYNJ. 1998. World Trade Center HVAC, Fire Protection, Plumbing Design Guidelines, Specifications and Standard Details. May 11.

PANYNJ. 1999. World Trade Center Mandated Fire Alarm Guidelines. March.

Stempler, Steven H. 1984. World Trade Center Tenants Manual. World Trade Operations Division. 
Section II

Post-Construction Fire Protection and Life Safety Modifications to the World Trade Center Towers 
This page intentionally left blank. 


\section{EXECUTIVE SUMMARY}

As part of the analysis of building and fire codes and standards of the National Institute of Standards and Technology (NIST) World Trade Center (WTC) Investigation, this report supports the effort to document and analyze the performancc of the fire protection and life safety systems of WTC 1 and WTC 2. The performance of the fire protection and life safety systems is ultimatcly affected by the changes made to the systems. The purpose of this section is to identify the repairs and/or modifications made to the fire protection and life safety systems on the affected floors of WTC 1 and WTC 2. Various programs were established to accomplish the modifications to the fire protection and life safety systems. The Port Authority of New York and New Jersey (PANYNJ) installed the backbones of the systems and required devices in the public spaces. The building tenants would then modify/extend the systems into the leased spaces. The following is a list of programs in progress or completed as of September 11, 2001:

- Corridor and tenant wall extension. This program was intended to extend the walls to the underside of the floor slab above giving the tenant the option of compartmentalizing or sprinklering the leased space to meet code requirements.

- Sprinkler and standpipe installation. This program was initiated in the 1980 s and was near completion in 2001. This program was initiated in response to Local Law 5.

- Fire alarm system installation. The fire alarm system was undergoing a major renovation at the time of the attacks. Soon after the 1993 bombing of the WTC, plans were initiated to install a new fire alarm system. Standpipe telephone jacks, smoke detectors, manual fire alarm pull boxes, loud speakers with voice communication capabilities, fire command stations, fire warden stations and strobes were installed throughout. For a more detailed description of the fire alarm system upgrade, refer to the NIST Investigation Project 4 reports.

- Re-fireproofing. This program was intended to provide the appropriate thickness of fireproofing materials to achieve a $2 \mathrm{~h}$ fire rating on the floors and $3 \mathrm{~h}$ on columns throughout the buildings.

- Passenger elevator modernization. This program was initiated because the equipment became obsolete. As part of the modernization project, firemen's recall functions were installed.

- Freight elevator signage installation. Appropriate signage was provided throughout the buildings as part of this program.

- Emergency lighting and exit sign enhancement. Emergency lights with battery packs were provided in stairs and elevators. The emergency lights werc also connected to emergency circuits. Exit signs were upgraded with modern LED illuminated signs. 
Other programs that were being developed but not yet implemented included:

- Correction of mechanical rooms exiting into the fire stairs.

- Identifying floors that have inadequate fire hose reach.

- Replacement of lobby carpeting not meeting the test requirements of the Building Code of the City of New York (BCNYC).

- Installation of fire stopping at duct/pipe penetrations.

- Installation of smoke dampers on the discharge side of all air-conditioning systems over $15,000 \mathrm{cfm}$.

Tenant alteration projects continuously modified the fire protection and life safety systems. As tenants moved in and out, new conditions (such as wall layouts and occupancy use) warranted a need for change. These changes within the tenant spaces mandated the need to modify the sprinkler system, fire alarm system, heating ventilating, and air conditioning system, emergency lighting and exit signs to fulfill PANYNJ and the BCNYC requirements. Tables $3-1$ and 3-2 in Chapter 3 of this report list the tenant alterations performed on the affected floors of WTC 1 and WTC 2. 


\section{Chapter 11 \\ INTRODUCTION}

Over the life of the World Trade Center (WTC) 1 and WTC 2, enhancements to the fire protection and life safety systems were made. Tenant alterations, fires, revised building code provisions, and new technology all contributed to the reasons for enhancing the systems. Changes made to the fire protection and life safety systems ultimately affected the building performance. Thus, in order to analyze the performance of the buildings in response to the September 11,2001, attacks, it is crucial to have the most up-to-date knowledge of the systems installed. The purpose of this section is to identify the repairs and/or modifications made to the fire protection and life safety systems on the affected floors of WTC 1 and WTC 2. The affected floors, for the purpose of this report, are the 94th through the 98th floors for WTC 1 and the 78th through the 84th floors for WTC 2.

As the building code provisions were updated, new tenants moved in and out, and technology advanced, the fire protection and life safety systems were modified. Modifications were accomplished through many short-term and long-term projects of varying magnitudes and objectives. Some modifications were the direct responsibility of the Port Authority of New York and New Jersey (PANYNJ) while other modifications were the responsibility of the tenant. The PANYNJ modified the common areas within the building (e.g., public corridors, stairways, utility closets, etc.) and installed the backbones of the fire protection and life safety systems. The building tenants, in turn, updated the leased spaces by modifying/extending the fire protection and life safety systems to accommodate the building code and mission continuity requirements within the tenant space. The base building modifications to the affected floors are summarized in Chapter 2, with tenant modifications of WTC 1 and WTC 2 summarized in Chapter 3. 
This page intentionally left blank. 


\section{Chapter 12 \\ BASE BuILding Modifications to AfFected FloORS}

The Port Authority of New York and New Jersey (PANYNJ) and various consultants continuously evaluated the condition of the multiple fire protection and life safety systems throughout the World Tradc Center (WTC) complex. Improvement programs were established to provide a basis for the preservation, repair and retrofit of the various systems. This chapter summarizes the base building fire protection and life safety programs developed for WTC 1 and WTC 2. Programs that were well under way or completed at the time of the September 11,2001, attacks are listed in Sec. 2.1. Programs that were being developed or still in the design process are listed in Sec. 2.2.

\subsection{MODIFICATION PROGRAMS IN PROGRESS OR COMPLETED AS OF SEPTEMBER 11, 2001}

A corridor wall and tenant separation program was in place to extend the walls to the underside of the floor slab above to minimize smoke spread, meet code requirements and give tenants the choice of compartmentalizing or sprinklering the tenant space. The wall extension project was a long-term program that was incorporated in new tenant alterations. Tenants were reimbursed by the PANYNJ as the work was performed (PANYNJ 1999). The necessity to complete the wall extension program was in question because of the sprinklerization program that was later developed (Merritt and Harris 2000a, 2000b).

In the 1980s and in order to comply with Local Law 5, the complete sprinklerization of WTC 1 and WTC 2 was initiated. Exact details on how this retrofit process was accomplished have not been completely identified. Documentation indicates that the core area mail and storage rooms, the fire standpipe and drain risers were initially installed to provide future extension of the sprinkler system as tenants moved in and out (Appendix A). In 2000, it was reported that the office floors of WTC 1 and WTC 2 were fully sprinklered with the exception of the electrical and telephone closets, most toilet rooms, the main lobby and the B-6 Level Mechanical Equipment Room (MER). A standpipe riser with a fire hose rack on each floor was installed in each stairway (Merritt and Harris 2000). Various fire pumps and water tanks were installed throughout the buildings to supply the appropriate water demand. Further tenant modifications to the sprinkler system are listed in Chapters 3 and 4 of this report.

The base building fire alarm system was modified numerous times affecting various components of the system; see Table 12-1 for a listing of PANYNJ contracts. Permanent standpipe telephone jacks were installed and activated on each floor of all fire stairways (PANYNJ 1999). A program to install return air smoke detectors and return air smoke detector annunciation requirements was in place and scheduled to be completed by the end of 2000 (PANYNJ 1999). Upon completion of the return air smoke detector program, a program to comply with elevator lobby smoke detector requirements was to be initiated (PANYNJ 1999). Further reports indicate that elevator lobbies were installed with smoke detectors. Manual fire alarm boxes were installed on all floors so that travel distance to a fire alarm box was less than $200 \mathrm{ft}$ (PANYNJ 1999). Loud speakers were installed in public corridors (PANYNJ 1999). The voice communication system was extended from the core corridors to the office areas. Fire command stations were installed in the lobbies of WTC 1 and WTC 2 (PANYNJ 1999). Soon after the 1993 
bombing, plans were made to install a new Style 7 fire alarm system throughout the WTC complex. The new system was designed to completely replace the existing system using a three-phase process.

Table 12-1. Contracts involved with the fire alarm upgrades.

\begin{tabular}{|l|l|}
\hline \multicolumn{1}{|c|}{ Contract } & \multicolumn{1}{c|}{ Description } \\
\hline WTC-499.18 & Tower MER Sprinkler Installation and Modification to Smoke Detection \\
& System
\end{tabular}

Key: EMR, ???

The program started in 1993 and was still being worked on in 2001 with phases one and two complete. By September 11, 2001, WTC 1 was approximately 85 percent complete and WTC 2 was approximately 80 percent complete, with an overall project completion of approximately 75 percent. The upgrade of the fire alarm system was estimated to cost $\$ 69$ million dollars. It was estimated that 25 percent of the original fire alarm system was still in service at the time of the attack (PACO 2002). In addition to the base building fire alarm system, tenants installed or extended the fire alarm system within the tenant spaces as necessary. Further tenant modifications of the fire alarm system are given in Chapters 3 and 4 of this report. More specific details of the upgrade and final system capabilities are identified in reports for Project 4, Active Fire Alarm Systems, of the National Institute of Standards and Technology Investigation. A general list of system upgrades are as follows:

- The existing American Multiplex system was replaced with a decentralized system that included six independent fire alarm sub-systems. Each of the six sub-systems was linked to a Network Command Center located in the Fire Command Station at the lobby of each of four WTC buildings (WTC1, WTC 2, WTC 4, WTC 5) with backup centers throughout the WTC. 
- Wall mounted strobes and eciling mounted spcakers werc installed in all corridors, bathrooms, common areas and all occupied tenant spaces.

- Addressablc area smoke detectors werc installed in all base building clcetrical and tclephonc elosets, mechanical rooms, elevator machine rooms and in elevator lobbies for elevator rccall. Duet mounted smoke deteetors and arca deteetors wcre installed in front of the return/supply air grills for fan shut down.

- Manual fire alarm boxes were installed next to eaeh stairway and in the main exits in the main lobbies.

- All existing sprinkler tamper and flow switches were connected via interface modules.

- All tenant proprietary fire alarm panels were conneeted to the fire alarm system via interface modules to transmit an alarm or trouble.

- A floor warden station was installed on every floor to establish two-way eommunieation between each floor and the Fire Command Station. A stairway standpipe fireline telephone jack was installed for the Fire Department.

An ongoing re-fireproofing program was under way to install an appropriate thickness to achieve a $2 \mathrm{~h}$ rating on floors as tenants vaeated a space (PANYNJ 1999; DPV 2002; Merritt and Harris 2000a, 2000b). As of 2000, approximately 30 floors of WTC 1 and WTC 2 were completed (Merritt and Harris 2000a, 2000b).

In 2000, a program to modernize all passenger elevator cabs with new interior finishes, overlay eontrollers, the Americans with Disabilities Act features and firemen's recall was completed. Phase two of the modernization program included retrofitting door operators and installing new door re-opening devices. The project was initiated because equipment beeame obsolete. As of 2000, 126 elevators were completed, 8 in progress and 104 not yet modernized (Merritt and Harris 2000a, 2000b). Additionally, the Merritt and Harris reports indieate venting of the elevator shafts in WTC 1 and WTC 2 was aecomplished through the elevator maehine rooms due to the configuration of the elevators in the central core. This arrangement is not permitted by American Society for Mechanical Engineers A17.1 but was accepted by PANYNJ as the only viable solution (Merritt and Harris 2000a, 2000b).

In 1999, freight elevator signage was installed throughout WTC 1 and WTC 2. The enhancement was performed under the PANYNJ job number WPM-6424.

The emergeney lighting and exit signs were upgraded subsequent to the 1993 bombing. The emergency lighting system was modified by providing fixtures with battery paeks in the stairs and connecting the lights to emergeney eircuits. All elevators were provided with emergency lighting with $2 \mathrm{~h}$ battery packs with selected fixtures connected to emergency circuits. The initial exit signs, which were illuminated with fluorescent lamps, were replaeed with modern LED illuminated exit signs. The program was aeeomplished from 1997 to 2000 (PACO 2002; Merritt and Harris 2000a, 2000b). 


\subsection{MODIFICATION PROGRAMS IN DEVELOPMENT}

In addition to the modification programs mentioned in Sec. 2.1 above, many other modification programs were planned. The following is a list of programs that were in the process of implementation as of September 11, 2001:

- Correct the configuration that has mechanical rooms exiting into fire stairs (PANYNJ 1999).

- Identify floors that have inadequate fire hose reach (PANYNJ 1999).

- Replacement of the carpeting in lobbies which do not meet the test requirements of the Building Code of the City of New York (PANYNJ 1999).

- Installation of fire stopping at duct/pipe penetrations (PANYNJ 1999).

- Installation of smoke dampers in the discharge of all air-conditioning systems over 15,000 cfm (PANYNJ 1999). 


\section{Chapter 13 \\ Tenant Modifications to Affected Floors}

Tenant alteration projects also modified the fire protection and life safety systems within World Trade Center (WTC) 1 and WTC 2. Tenant spaces were modified to accommodate new floor layouts as tenants moved in and out. New wall layouts, changed occupancy use, and mission continuity objectives in tenant spaces introduced different code requirements.

Generally speaking, the tenant alterations performed in WTC 1 and WTC 2 included typical business occupancy modifications to the primary fire protection and life safety systems. A typical office alteration included rearranging walls to accommodate the desired layout of the tenant while maintaining proper fire separations and divisions from other tenants within the building. Fire and/or smoke dampers were installed in the heating, ventilating, and air conditioning systems at penetrations of fire rated walls. The base building wet pipe sprinkler system was modified by the addition of sprinkler heads and branchlines in the tenant space, which was required by National Fire Protection Association (NFPA) 13 and the Building Code of the City of New York (BCNYC). Hydraulic calculations were performed to justify the pipe sizes of the branchlines as necessary. Documentation indicates that calculations were conducted back to the floor control valve assembly of each floor where system pressures were previously known. Fire alarm and voice communication systems were installed within each tenant space as required by NFPA 72 and the BCNYC. Each tenant fire alarm and voice communication system was designed to be connected to the base building system where signals could be reported at the Fire Command Station of each building. Providing exit and emergency lighting within the tenant space, which is required by the $\mathrm{BCNYC}$, was also included in the tenant alteration project. All of the system modifications were submitted to the Port Authority of New York and New Jersey (PANYNJ) for approval or were approved using the self-certification process established by the PANYNJ. PANYNJ Tenant Construction Review Manuals were used for establishing minimum design criteria and design details.

Tables 13-1 and 13-2 list the tenant alterations that were performed on the affected floors of WTC 1 and WTC 2. Any variances from the typical office modification are noted. 


\subsection{WTC 1 TENANT ALTERATIONS ON AFFECTED FLOORS (78-84)}

Table 13-1. Summary of WTC 1 tenant modifications within affected floors.

\begin{tabular}{|l|l|l|l|l|l|}
\hline \multicolumn{1}{|c|}{ TAA\# } & Floor(s) & $\begin{array}{l}\text { Location } \\
\text { on floor }\end{array}$ & Year & \multicolumn{1}{c|}{ Tenant } & \multicolumn{1}{c|}{ Systems Modified } \\
\hline W98-1199 & 94 & North & 1998 & Guy Carpenter & Typical \\
\hline W98-1197 & 94 & South & 1998 & Marsh and McLennan & Typical \\
\hline W-91093 & 94 & Core & 1991 & Deloitte and Touche & Add sprinkler in electrical closet \\
\hline W-4146 & 95 & Southeast & 1988 & Sumitomo Bank, Ltd. & Typical \\
\hline W-4183 & 95 & Northwest & 1988 & Sumitomo Bank, Ltd. & Typical \\
\hline W00-1135 & 95 & North & 2000 & Marsh and McLennan & $\begin{array}{l}\text { Typical, new pre-action sprinkler } \\
\text { system }\end{array}$ \\
\hline W98-1151 & $95-98$ & $\begin{array}{l}\text { Entire } \\
\text { floor }\end{array}$ & 1998 & PANYNJ & $\begin{array}{l}\text { Demolition of floor, fire alarm } \\
\text { system to remain operable, } \\
\text { sprinklers to be removed }\end{array}$ \\
\hline W98-1197 & $95-98$ & $\begin{array}{l}\text { Entire } \\
\text { floor }\end{array}$ & 1998 & Marsh and McLennan & $\begin{array}{l}\text { Typical, new pre-action sprinkler } \\
\text { systems and additional stairs }\end{array}$ \\
\hline W-4112 & 97 & North & 1988 & Deloitte Haskins and Sells & Typical \\
\hline W-4412 & 97 & Entire & 1989 & Deloitte Haskins and Sells & $\begin{array}{l}\text { Demolition of floor, sprinkler and } \\
\text { fire alarm system to remain } \\
\text { operable }\end{array}$ \\
\hline W-4417 & 97 & Entire & 1990 & Deloitte Haskins and Sells & Typical \\
\hline
\end{tabular}

Key: TAA, Tenant Alteration Application. 


\subsection{WTC 2 TENANT ALTERATIONS ON AFFECTED FLOORS (94-98)}

Table 13-2. Summary of WTC 2 tenant modifications within affected floors.

\begin{tabular}{|l|l|l|l|l|l|}
\hline \multicolumn{1}{|c|}{ TAA\# } & Floor(s) & $\begin{array}{c}\text { Location } \\
\text { on floor }\end{array}$ & Year & \multicolumn{1}{|c|}{ Tenant } & \multicolumn{1}{|c|}{ Systems Modified } \\
\hline W-4415 & 78 & Unknown & 1989 & Fuji Bank & Typical \\
\hline W97-2208 & 78 & North & 1997 & Sky Markets & Egress analysis \\
\hline W96-2192 & 78 & Unknown & 1997 & First Commercial Bank & Typical \\
\hline WX-0137 & 78 & $\begin{array}{l}\text { Core, } \\
\text { Southwest }\end{array}$ & 1998 & PANYNJ & Typical \\
\hline WC98-2133 & 78 & Southeast & 1998 & Georgeson and Co., Inc. & $\begin{array}{l}\text { Typical, including escalator to } \\
\text { 77th floor }\end{array}$ \\
\hline WPM-6417 & 78 & Core & 1999 & Fuji Bank & Typical \\
\hline W99-2146 & 78 & Southeast & 1999 & Baseline & Typical \\
\hline W01-1139 & 78 & North & 2001 & Sky Markets & $\begin{array}{l}\text { Partial demolition of floor, } \\
\text { sprinklers to be removed }\end{array}$ \\
\hline W99-2125 & 80 & East & 1999 & Fuji Bank & Typical \\
\hline W01-2149 & 80 & Unknown & 2001 & Fuji Bank & Typical \\
\hline W-4623 & 80, & $\begin{array}{l}\text { Northeast, } \\
\text { Southwest }\end{array}$ & $\begin{array}{l}1990, \\
1990\end{array}$ & Fuji Bank & Typical \\
\hline W97-2175 & 82 & Southeast & 1997 & Fuji Bank & Typical \\
\hline W97-2112 & 83 & Unknown & 1997 & AON & Unknown \\
\hline W99-2197 & 83 & West & 1999 & IQ Financial Systems & Typical \\
\hline W99-2185 & 83 & Southeast & 1999 & $\begin{array}{l}\text { The Chuo Trust and } \\
\text { Banking Co. }\end{array}$ & Typical \\
\hline W94-2117 & 84 & West & 1994 & Euro Brokers & Typical \\
\hline
\end{tabular}

Key: TAA, Tenant Alteration Application. 
This page intentionally left blank. 


\section{Chapter 14 \\ REFERENCES}

DPV. 2002. William and Connolly, personal communication to file, World Trade Center Fire Protection System. July 15.

McAllister, T., ed. 2002. World Trade Center Building Performance Study: Data Collection, Preliminary Observations, and Recommendations. FEMA 403. Federal Emergency Management Agency. Washington, DC, May.

Merrit and Harris, Inc. 2000a. Property Condition Assessment of World Trade Center Portfolio, One World Trade Center. New York, NY, December 6.

Merrit and Harris, Inc. 2000b. Property Condition Assessment of World Trade Center Portfolio, Two World Trade Center. New York, NY, December 6.

PACO Group, Inc and Flack and Kurtz, Inc. 2002. General Description of All Building Systems and the Capital Program. January 14.

PANYNJ (The Port Authority of New York and New Jersey). 1999. World Trade Center - Code Compliance Evaluation. New York, NY, October 15.

Rivera, C.M. 1993. Fire and Building Codes and the Jurisdiction and Compliance of Federal, State Authorities and Foreign Government Buildings. The City of New York Fire Department. New York, NY, March 25.

Silverstein Properties. World Trade Center Property Risk Report. New York, NY. 
This page intentionally left blank. 


\section{Appendix A \\ REPRODUCTION OF REPORT ON FIRE SAFETY OF THE WORLD TRADE CENTER}

This report is reproduced with permission of The Port Authority of New York and New Jersey. 
This page intentionally left blank. 
REPORT ON FIRE, SAFETY OF

THE WORI,D TRADE CENTER

Contents

Page

Part I - Repurt on Firr of Folirmary 13, 1975

$1-10$

Part II - Evaluation of Iife Sar.sty

$11-19$

January 1976

Reproduced with permission of The Port Authority of New York and New Jersey. 


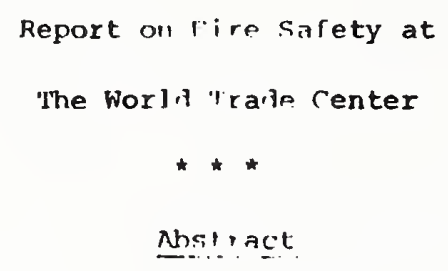

It has always been the Port Authority's intention to comply with Local J.aw 5 since it is our general policy to voluntarily comply with local building codes and in many cases to far exceed the specified requireinerits of same. A case in proint is the world Trade Center project. Before Allar.lmont of Local Law 5 in 1973, 11.. Nort Authority staff and its hi-rise (m) llin following features were in...r...r.mit in the design and installed in the Worlil Trade renter complex which westo iver and ahove existing code reguirements at the rime:

- Smoke deferiurs on each floor at return air lurts.

- Elevators relurn in qround floor for fireman roaliness.

- Fire alarm hoxes on each floor with voice communication.

- Public address system in corridors.

- Smoke purge confiquration for airconditioning system.

- Fire director's unit central control console.$$
\text { * * * }
$$

During the period of desiqn, which beqan in 1967, the Port Authority worked closely with the New York City Fire Department on the development of these features as well as familiarization of the Fire Department with the
} 
$B$ -

building systems and access. In 1970, the Port Authority further cooperated with the Fire Department by making the 30 Church street building available, immediately prior to its demolition, for the fire Department and its consultant to conduct controlled fire tests and evaluate the principle of stair pressurization to provide safe eqress from a fire floor. Partially, as a result of these actual fire test conditions of staix pressurization, requirements for such a pressurization system were included in one of the options of Local Law 5.

After the World Tratin Canter fire last spring, Dr. Ronan appointed a Comnissioners' Fire rommittee hented by Commissioner George Berlinger, and inrluding Commissioners Axtell, rijbert and Hellmuth. This committee dixes:ted rort Authority stoff to torrounhly review all aspects of the World Tradc Center fire and the life safoty provisions of the structures, including the conforming of the complex to the provisions of Local Law 5 . The latter provides for the selection of eithis a crmpartmentation option or a sprinkler option. The comnittee further ret.lined an independent consultant to review the World Trade Center life safety urovisions.

The consultant concludind that the existing structural fire retardants of the building are sufficient to make the probability of serious structural damage extremely remote and that the deqree of vertical compartmentation provided sufficiently limits the spread of fire in the structures, but that the spread of smoke requires attention from a life safety standpoint.

The consultant further concludind that...

"The results of these comparative analyses indicated that, in our opinion, either of the two fire protection 
options provided for under Local Law 5 would provide a good level of occupant life safety within the World Trade Center complex, provided that whichever is selected is supplemented by rertajn additional measures."

The additional provisions recommended by the consultant over and above the compartmentation option are summarized as follows:

1) Sprinklering of all roms in the central corridor area which could contribute excessive quantities of smoke to the corridor systems;

2) Doors which are normally krpt open to the corridor system should be equipped with electro-magnetic "hold-open" devices which would in activated to close the doors;

3) Provide fail-safe automati: door closers, arranged to close upon activation by simoke detectors for the overhead rolling fire doors separating the lielow grade truck dock from the elevator lobby;

4) Perform an investirntion to determine the optimum mode of operation of the building air-conditioning system to remove smoke from the central core compartments without contaminating adjacent areas.

The additional provisions recommended by the consultant over and above the sprinkler option are items 2,3 and 4 above and the following. Provide automatic smoke detection in immediate vicinity of elevators at each floor level. 
In a separate report, propared by the New York Board of Fire Underwriters, an investigation of the February 13 th, 1975 fire, the Board wrote:

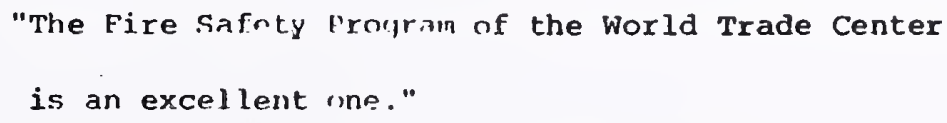

The Board, while recommending examination of additional safety measures, further observed:
"In the overa]1, thpse towers may be considered as among lhe salist huillings. in New York City."

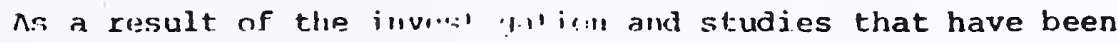

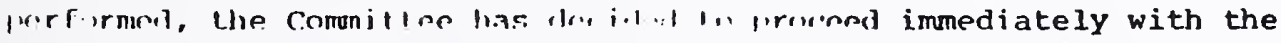
Following steps in compliancrs w.1, $\ldots . ., 1$, 5 , and the additional items

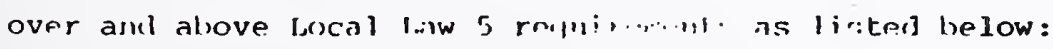

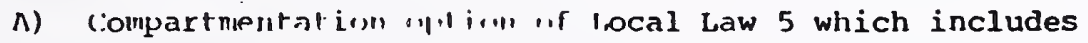
the following major : : I fl': :

1) Expansion of fil. $, 1, i$ ril and communication system.

2) The installation ".r smiske detectors in elevator lobbies and addilional smoke detectors at air return inlets.

3) Compartmentation wf spirses into 7500 square foot areas.

4) Proceed with stair irs:surization design and prototype pressurization testing in the structure for World Trade Center Towers. 
B) Additional items over and above Local Law 5:

1) The implementation of all the recomendations from the consultant and staff.

2) Sprinkler all janitor closets, mail rooms, file rooms, storage rooms, etc. in the central core of each flour of each tower and make provisions for extension of sprinkler system to any areas of such usinge requiring same as occupancy may change. 
PART I

Report on Fire of February 13, 1975

\section{Introduction}

After the World Trade Center fire last spring, Dr. Ronan appointed a Commissioners 'Fire Committee which consisted of commissioners Berlinger, Axtell, Gilbert and Hellmuth. Commissioner Berlinger was appointed chairman of the committee. This comittee directed Port Authority staff to thoxoughly investigate and review 1 he extnnt of the fire and smoke damage, the origin of the fire, thr runctioning of the building systems for prevention, detection and figliting, ff fires, and safety procedures. The Port Authority staff members apinin! ’. l., carry out this assignment were Messrs. R. M. Monti, Chief Fnqiunor; R. $r$. Ahrallams, Chief Contract Division, Law; J. DeMarinis, Manager, Risk Mallacjmmnnt Division. The Comuissioners' Fire Committee also retained thr srivires of an independent consultant to review all safety aspects of World rrade Center operations regarding fire protection.

Development of the Fire

The fire started in the office of R. J. Saunders, Inc., Suite no. 1119. It extended north to two smaller adjacent offices, where it was stopped in that direction and extended to the southwest corner of the Saunders office, where it was stopped in that direction. A telephone closet containing vertical telephone cables, and other equipment is located adjacent to the Saunders mail area. The closet had a door with ventilation 
louvers. This telephone closet communicated vertically with identical telephone closets above and below through an opening containing vertical telephone cables, and other equipment was located adjacent to the Saunders mail area. The closet has a door with ventilation louvers. This telephone closet communicated vertically with identical telephone closets above and below through an opening of about 1.5 square feet cut in the concrete slab. All such southeast telephone closets on floors seven (7) through forty $(40)$ created a vertical opening within the building; their doors are normally kept closed. Fire extended to the inside of the llth floor telephone closet and commuricated to closets on floors above and below through the concrete slab openings, causing damage to telephone closets on the 10th, 12th, and 13th floors and lesser damage on the 9th, 14th, 15th and 16 th floors. Ignition of the plastic insulation and the plywood boards, used for attaching the telephone equipment to the walls of the closet, occurred. The fire was then transmitted to the 10 th and 12 th floor closets. While it must have taken some period of time for the fire to fully develop within this telephone closel, it must be noted that this area within the Saunders suite was probably the last reached by the fire department.

* The openings in the telephone closets were necessarily left during construction for installation of telephone cable and were planned eventually to be closed up around the cables as soon as further cable installation was completed, e.g. for the television broadcasting facilities intended to operate at the top of Tower A. A contract for such closing has been awarded and the work has been completed. 
In summary the chronological sequence of the observed events of the fire was as follows:

11:55 p.m., (Thursday, February 13): Cleaning porter in corridor observed fire under door of suite 1119; he reported to the World Trade Center control desk via the fire alarm emergency telephone in the 1lth floor corridor; New York City Fire Department notified and Port Authority police officers dispatched to the 11th floor, where they activated the building standpipe system and commenced to wet down the corridor door of Suite 1119 .

12:01 a.m., first Fire Department units entered the World Trade Center.

12:09 a.m., Fire Department units arrived on 11th floor.

12:15 a.m.. second group of Fire Department units arrived, in response to second alarm, transmitted by Fire Department officer on scene.

12:42 a.m., third group of Fire Department units arrived in response to third alarm, transmitted by Fire Department officer on scene; Fire Comissioner $0^{\prime H a g a s}$ also arrived at this time.

3:22 a.m.. Fire Department indicated all clear condition, after a floor to floor check up to the 4lst floor.

The Fire Department used water from the World Trade Center building standpipe system, to which it connected its hoses. The Department stated that there was a sufficient supply of water for fire extinguishment. 


\section{Cause of Fire - Suspected Arson}

In July 1975 a Temco Maintenance Company employee was charged in an indictment with setting the Fepruary 13, 1975 fire as well as five subsequent world Trade Center fires.

\section{Extent of Fire Damage}

The fire damage occurred mainly on the llth floor, in the southeast quadrant. Whatever fire damage occurved on other floors was generally limited to the telephone closet in the southeast quadrant of floors 9 through 14 and a small portion of spaces immediately adjacent to the telephone closets.

Smoke damage occurred in varying degrees in the adjoining sections of the 1lth floor; elsewhere, the significant smoke damage occurred on the loth, 12 th, 13 th and 14 th floors. Smoke lamage on floors 15 through 23 was generally limited to the area of the tolephone closet in the southeast quadrant and a small portion of the tenant spaces immediately adjacent, in decreasing degrees.

Existing Building System Evaluation World Trade Center Building System - Building Code

For further information there follows a description of the World Trade Center building systems for fire protection and extinguishment, together with an account of the Port Authority's conformance to the standards established by the New York City Building Code, including the amendments known as Local Law 5/73, even though the State and its agencies, such as the Port Authority, are not subject to City building codes. 
References are made in various places to the 1968 bullding code, since that code would have applied to construction generally at the time the World Trade Center was built. A separate discussion addresses itself to the amendments of 1973 , i.e. Local Law No. 5. Following is a description of the existing systems at the World Trade Center:

\section{Air Distribution Systems}

The Trade Center alr distribution systems, in addition to conforming to all the 1968 NYC Building Code requirements, also possess an additional mode of operation which can be utilized to assist in controlling smoke from a fire. In this mode the return air shaft and fan systems are used to exhaust from the office snaces to the exterior of the building. The core system is also operated to provide outside air to the corridors.*

\section{Fire Standpipe System}

The standpipe system consists of manually activated fire pumps rated at $750 \mathrm{GPM}$ each located at the Service Level, 7th Floor, 4lst Floor and 75th Floor. In addition, there

* There are four mechanical equipment rooms serving each tower. These equipment rooms, which contain the air handling systems, are located on the 7th, 4lst, 75th and 108th floors. The air distribution from these floors can be generally divided into three sub-systems, the peripheral, the interior and the core. The peripheral system serves the floor area around the exterior wall and feeds up from the ceiling of the floor below to induction units at the exterior wall. The interior system serves the remaining office floor area through ductwork located above the hung celling with air outlets combined with the light fixtures. Air returns to the equipment room through other light fixtures into the ceiling area, which acts as a plenum, and from the plenum to shafts running vertically at the building core. The core system serves the corridor and elevator lobbies. 
are $5,000 \mathrm{gal}$. water storage tanks located on the 20 th Floor, 4lst Floor, 75th Floor and roof. There are also a minimum of three flre hose racks on each floor capable of reaching every part of that floor. The standpipe system conforms to the 1968. Building Code. Initially, during the fighting of the fire, Tower A pump experienced some difficulty with the speed control panel. Tower B pump, which was designed to be operable also for Tower A; was then used. The Tower A pump was returned to use during the fire fighting, without difficulty. The standpipe system functioned to the complete satisfaction of the Fire Department throughout. 
Smoke Detectors

Smoke detectors were installed in each return air fan discharge duct and each supply unit. Upon actuation any one of these detectors will shut down all the ventilation fans within the respective quadrant of the mechanical room and initiate a print-out and visual and audible alarms in the central control station. This installation is in conformance with the 1968 Building Code.

In addition to the smoke detectors previously noted, under a contract prepared prior to enactment of Local Law 5, detectors with.supervised circuits have been installed at 4 locations on each floor of the Tower Buildings. These detectors aro focated above the hung ceiling directly in front of a return air $A \cdots,+1$ intake and indicate an alarm condition, by floor, at the Port Nullociry Police Desk. In the building zone in which the fire occurred, detoctor: were installed and operational on Floors 9 through 19. These deterto:- jnitiated a print-out at the police desk.

\section{Elevator Control}

All passenger elevator cais are capable of being recalled to their respective lobbies. This contrnl "ver-rides all individual floor hall calls, prevents heat from calling it car to a "fire floor" and makes the car available for manual operation by building personnel and the Fire Department.

This is in excess of the requirrments of the 1968 code, which required only one elevator capable of serving each floor equipped for emergency return and Fire Department. Service. 


\section{Fire Alarm System}

On each floor of each of the World Trade Center buildings, at a. central corridor location, there was a fire alarm emergency telephone which connected with a control center next to the Police Desk on the lower level of Tower A. (In addition, the Port nuthority has applied on telephones in its own offices, and has distributed to tenants for their application on their telephones, a conspicuous red label giving the telephone number of the Police Desk to call in case of emergency.) An interior fire alarm system including voice communication has been installed on each floor in the core corridor. Incoming fire calls to the control center illuminate the indicating lamp of a particular fire station atu sound an audible signal. In addition, an emergency public address system provides communication from the control center to all locations equipped wilh In:1.lspeakers, as selected by the control center operator. The syst.m ils. can transmit, through two individual microphones, different messages to : ir.locted loudspeaker areas. It can also receive communications from the elentor starter panels. Pre-recorded announcements can be transmitted through 1 his system and announcements originating from the elevator starter panels can he 1 ralismitted through this console to selected loudspeakers. Fire alarm warble tones ran be transmitted to any floor or floors from one of these microphones.

The control console is equipped with separate indicator lights and switches for each area. The indicating lights provide visual information as to which loudspeaker area is in operation. In addition, a warning light system is included to indicate failure of any of the amplifiers located in a remote location. These amplifiers are tested automatically at intervals or can be tested manually by operating personnel. Visual indication of amplifier failure is also provided on the front panel of each power amplifier. 
Reguirements of Local Law No. $5 / 73$

The fire safety amendments to the New York City Building Code embodied in Local Law 5 adopted in 1973 prescribe various measures to be complied with by various dates. The Port Authority has complied with those for which compliance dates have already occurred, and in fact had incorporated in the World Trade Center design a number of such measures before they were adopted under Local Law 5. Some examples are as follows.* Interior fire alarm system, including voice communication:

The World Trade Center was designed and constructed with a fire alarm and voice communication system in the corridors before any such system was required by code. Local Law 5 required such a system to be installed, including its extension into offict: spaces as well as stairways. A contract has been prepared and awarded to extend the system into the office spaces and stairways.

Automatic "homing" of elevators, and elevator in readiness:

Manual controls presently installed in the World Trade Center permit recall of all elevators to their home floor, overriding any manual or heat activation of call buttons, where they can be placed under the command of the Fire Department for fire fighting operations. This too was beyond the requirements of the 1968 code. Local Law 5 now requires automatic homing of elevators when

* While combustibility of furnishings is not dealt with in Local Law 5 or other parts of the New York City Building Code, the Port Authority addressed itself to this problem in planning the World Trade Center and after extensive study adopted and applied standards rigidly limiting its own furnishings to a low rate of flammability. A copy of the Port Authority's flanmability standards was communicated to tenants, pointing out the advisability of their use. 
a smoke detector, to be installed in the elevator lobby of each floor, is activated. Such additional smoke detectors and automatic activation will be installed at the world Trade center.

\section{Sprinklers or Compartmentation and Other Measures}

Under Local Law 5, ownexs of buildings (existing and future) of a class in which the World Trade Center would be included, are given the option of sprinklering throughout or of installing certain measures such as compartmentation of each floor into maximum areas of 7,500 square feet each separated by fire rated partitions, as well as smoke detectors as above described and pressurization of stnirwells.

In certain types of loraliuns, such as below grade areas and restaurants, and other commercial spmens, sprinklering is required without allowance for an option, and in tho:" lucations the World Trade Center as originally constructed included sprinklexs.

\section{Fire Safety Plan}

Local Law 5 calls for a plan of regular fire drills and evacuation procedures, approved by the City, under the supervision and control of a building fire safety director and one or more deputies. The Port Authority's plan exceeds these requirements, anl the New York Board of Fire Underwriters, after investigating the February $13+\mathrm{h}$ fire, observed: "The Fire Safety, Program of the World Trade Center is an excellent one." The Board, while recomending examination of additional safety measures, such as limiting combustibility of furnishings, further observed: "In the overall, these towers may be considered as among the safest buildings in New York City." See Page 10 of The New York Board of Fire Underwriters report. 
$-11-$

PART II

Evaluation of Life Safety

The World Trade center contains a complete fire protection and life safety installation which is itemized in the following sections. Furthermore, as indicated herein, additional measures will be implemented to enhance the present standards. 
1. Existing Life Safety Features

As noted in Part I of this report, the world Trade center has extensive life safety features which are in accordance with and beyond the requirements of New York City Code. These features include the following :

- fireproof construotion

- fire standpipe system

- smoke purge mode for air conditioning systems

- fire alarm and voice communication system

- sprinklers for restaurants, concession areas, and other public areas

- elevator return for Fire Department service

- smoke detectors at the return air system on each floor

- smoke detectors at the main air conditioning system fans.

The above protective systems are described in Part I of this report. 


\section{Off Hour Protection}

As previously noted, smoke detectors are installed at the return air intakes in four locations on each floor. Tests were conducted to determine the effective time lapse for detection by initiation of smoke bombs. The most remote office area with different combinations of fans operating. As a result of these tests, it is current procedure to operate one return air fan to each quadrant of the building throughout the off-hour period. This procedure will permit detection of a fire in its incipient stage within a maximum of five minutes. 


\section{Proposed Life Safety Features}

To further improve the life safety provisions with the Trade Center and to include protective measures required by Local Law 5 , the following steps are underway.

Elevator Lobby Smoke Detectors

A contract for the installation of smoke detectors in each elevator lobby has been prepared and bids received. The activation of any detector would automatically cause all elevators within the bank serving that floor to return to their respective lobby to permit full use by the Fire Department. Extension of Fire Alarm and Communication System

As previously noted in Part $I$, the present alarm system which includer voice communication between the Police Deck as well as communications through speaker systems in the core corridors on each floor, will be extended to provide warble tone alarm within the office areas and message communications within the stairways. A contract for this work has been awarded and is underway.

\section{Plenum Segregation}

Where not presently installed, the walls delineating the corridors will be carried to the underside of the floor slab above to minimize smoke spread.

\section{Stair Pressurization Studies}

To provide the added safety of insuring smoke-free stalrways, a study is underway to evaluate the feasibility and effectiveness of pressurizing the stairways relative to the office areas. This study includes a study of technical papers prepared throughout the world, a re-review of the tests conducted at 30 Church street, an inspection of the 50-story Seattle bank building which has 
an operational stair pressurization system, preliminary testing at the world Trade Center to determine the methodology and instrumentation required for conducting an in-situ survey of the World Trade Center stalrs prototype system to pressurize 40 floors in one stairway.

\section{Sprinkler Extension Provision}

In addition to sprinklering the core area mail and storage rooms, supplementary fire standpipe and drainage rigers wil provide extension of the sprinkler system as future occupancy changes or as conditions may dictate.

\section{Consultants Life Safety Survey of the World Trade Center}

In addition to the studies and investigations performed by staff for Iife safety protection in the World Trade Center towers, a consultant was engaged by the Port Authority to make a survey. The consultant engaged for the survey was the National Loss Control Service Corporation, an organization which has performed many similar investigations for Insurance Companies and other organizations in the past.

The premises upon which this survey was conducted started with the realization that most occupants of huildings of this type will remain inside the complex for the duration of the fire incident. Thus, the building must provide safe-refuge, readily accesible for all occupants, where a tenable atmosphere can be maintained. The consultant set as criteria that the basic requirements for an area to remain tenable are:

1. maintain structural integrity of the building:

2. absence of exposure to a direct flame;

3. presence of sufficient oxygen for life support;

4. absence of toxic combustion products at concentrations 


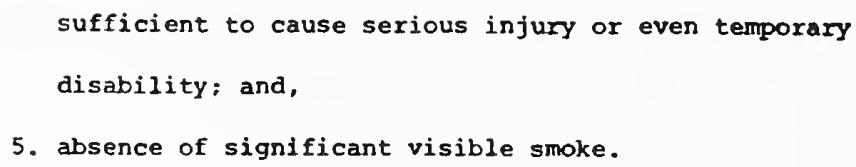

In the consultant's survey of the Trade Center, he established that the structural fire resistance of the building is sufficient to make the probability of serious progressive structural collapse extremely remote, and the degree of vertical compartmentation effectively limits the spread of fire and its attendant oxygen depletion to the floor of fire origin. Adequate exit capacity for the fire floor along with the presence of the Fire Safety Plan to evacuate the fire floor and the floor above, limits the exposure of building occupants to direct fire effects. Therefore, the consultant concluded; "it is the spread of smoke and toxic combustion products that require principal attention from a life safety standpoint."

On the basis of these premises the consultant proceeded to study the effect of fires originating in different areas of the complex, and the effects of these fires on the life safety of the occupants. In completing his studies and evaluations of the World Trade Center Towers, which included a comparative analysis of the relative life safety of the occupants relative to conforming the towers with either the compartmentation option or sprinkler option of Local Law 5, the consultant concluded that either of the two fire protection options provided for uncer Local Law 5 would provide a good level of occupant life safety within the World Trade Center complex, provided that whichever is selected, it is supplemented by certain additional measures. In the case of the compartmentation option, the consultant recommended that this option be supplemented with the following additional features:

A) Sprinklering of rooms in the central corridor area 
which could contribute excessive quantities of smoke to the corridor systems.

B) Doors which are normally kept open to the corridor system should be equipped with electro-magnetic "hold-open" devices and inter-connected to smoke detection devices to activate the closing of the door.

c) Provide fail-safe automatic door closers, arranged to close upon activation by smoke detectors for the overhead rolling fire doors separating the below grade truck door from the elevator lobby.

D) Perform an investigation to determine the optimum mode of operation of the building air conditioning system to remove smoke from the central core compartments w1thout contaminating adjacent areas.

In the case of the sprinkler option, the consultant recommended that this option be supplemented with items B, C and D noted above for the compartmentation option, and that in addition, automatic smoke detection, in the imediate vicinity of elevators at each floor level, should also be provided. 


\section{Summary and Conclusions}

As a result of the studies and investigations performed by both staff and consultants, it has been concluded that the World Trade Center Towers do provide life safety protection for its inhabitants. This life safety protection can be enhanced by the incorporation of several improvements into the structures as follows:

1. The openings between floors of telephone closets, which was a source of fire spread during the February 13, 1975 fire should be closed. This work has been accomplished to prevent any reoccurrences of a similar condition;

2. In addition, the Port Authority will proceed with the compartmentation option of Local Law 5 including all of its requirements for fire alarm, communications and stairway pressurization;

3. Sprinklering of all storage rooms, janitor closets, mail rooms and file rooms in the central core of each floor.

4. Building additional sprinkler capacity and provisions for extension of a sprinkler system to any area of such usage requiring it in the event of an occupancy change.

5. Equipping those doors which are normally kept open to the corridor system, such as doors at consumer service areas, with electromagnetic "hold open" devices which would be activated by smoke detectors to close the doors.

6. Providing fail-safe automatic doors closers, arranged to close upon activation by smoke detectors, for the overhead rolling fire doors separating the below-grade truck dock from the elevator lobby. 
7. Developing an optimum mode of operation of the buistring air-conditioning system to remove smoke from the central cose compar:ments without contaminating adjacent areas. 
This page intentionally left blank. 
